\title{
What is the effect of unconventional monetary policy on bank performance?
}

\author{
Emmanuel Mamatzakis ${ }^{1}$ and Theodora Bermpei ${ }^{2}$
}

\begin{abstract}
April 2016
Abstract

This paper examines the relationship between unconventional monetary policy and the US banking performance. Unconventional monetary policy is captured through the central bank's assets and excess reserves. Results show that unconventional monetary policy has a negative relationship with bank performance. Further analysis shows that the negative association between unconventional monetary policy and performance is mitigated for banks with a high level of asset diversification and low deposit funding. We also find that the negative relationship between unconventional monetary policy and performance subdues for deposit insured financial institutions. Finally, we use dynamic panel threshold analysis which reveals that the negative association between unconventional monetary policy and bank performance is particularly pronounced above the reported threshold value.
\end{abstract}

Keywords: Unconventional Monetary Policy, Bank Performance, Deposit Insurance Coverage, Dynamic Threshold Analysis.

JEL classification: G21; G01; E43; E52

\footnotetext{
${ }^{1}$ School of Business, Management and Economics, University of Sussex, Jubilee Building, Brighton, BN1 9SL, United Kingdom. ${ }^{2}$ Nottingham Business School, Nottingham Trent University, Newton Building, Nottingham, NG1 4BU, United Kingdom.

Corresponding author: Theodora Bermpei, theodora.bermpei@ntu.ac.uk.
} 


\section{Introduction}

Responding to the financial meltdown in 2008, the Federal Reserve (Fed) in the US has been actively engaged in monetary expansion of immense proportions. Only as part of the Fed's large-scale asset purchases (LSAPs) programmes, trillions of the US long-term Treasury bonds and mortgage-backed securities (MBS) were purchased over the 2008-2013 period. It does not come as a surprise, therefore, that a lot of emphasis has been placed by academics and policy makers alike on understanding the impact of unconventional monetary policy (Joyce et al., 2012; Miles, 2014; Svensson, 2014). Along these lines, there has been a growing literature that examines the effect of interest rates on the risk-taking of banks (Delis et al., 2011; Altunbas et al., 2012; Fungacova et al., 2014; Buch et al., 2014; Ioannidou et al., 2015). This paper tries to bridge a gap in the existing literature by examining the underlying relationship between the unconventional monetary policies (UMPs), as measured by central bank's assets and excess reserves, and the performance of the US commercial and saving banks controlling for bankspecific and country-level variables.

Although, there is a large volume of empirical literature regarding the broader economic impact of UMPs, there is rather limited evidence with regards to the relationship between UMPs and bank performance (Montecino and Epstein, 2014; Lambert and Ueda, 2014). Mostly, since the first round of the Fed's asset purchases in 2008, numerous studies offer explanations on the effectiveness of UMPs on asset prices, interest rates and a number of other macroeconomic variables (Krishnamurthy and Jorgensen, 2011; D’Amico et al., 2012; Wright et al., 2012; Kapetanios et al., 2012; Chen et al., 2012; Swanson et al., 2014; Rogers et al., 2014; Bowman et al., 2015). Some studies employ high frequency data and look at the impact of the Fed policy announcements on long term interest rates (Krishnamurthy and Jorgensen, 2011; D’Amico et al., 2012; Wright et al., 2012; Swanson et al., 2014) sovereign yields, stock prices and foreign exchange rates (Rogers et al., 2014; Bowman et al., 2015). Other studies look at the impact of UMPs on output and inflation (Kapetanios et al., 2012; Chen et al., 2012). Some other studies also investigate the association between UMPs and financial stability (Gilchrist and Zakrajsek, 2013; Chodorow-Reich, 2014). Gilchrist and Zakrajsek (2013) examine the effect of UMPs on 
corporate risk for commercial and investment banks over the 2008-2011 period. They conclude that UMPs increase corporate risk for the period under study. Similarly, Chodorow-Reich (2014) examines the effect of UMPs on risk-taking for a sample of insurers, and mutual funds from 2008 to 2013 period. The author finds some evidence of positive association between UMP and risk for the 2010-2013 period. The reported positive impact of UMP on bank risktaking lends empirical support to the 'portfolio balance' channel that is introduced by Tobin $(1963,1969) .^{2}$

Turning now to the effect of UMPs on bank performance this could be explained through its impact on bank's interest margins which is an important source of bank profitability. Bank's interest margin reflects the net interest income that arises from the difference between the short term (deposit) rate and long term (lending) rate (Delis and Kouretas, 2011). When the Fed has initiated UMPs, the short term interest rate has already reached the zero lower bounds. Furthermore, expansionary monetary policies decrease long term interest rates consistent with previous empirical studies (Krishnamurthy and Jorgensen, 2011; D’Amico et al., 2012; Wright et al., 2012; Swanson et al., 2014). Therefore, a reduction in the long term interest rates due to UMPs would decrease the difference between these long term interest rates and the short term interest rates that would consequently supress the interest margins. The extant literature points to two channels that UMPs, particularly LSAPs, could reduce long term interest rates. One is the 'portfolio balance' channel according to which the Fed's LSAPs could affect the long term interest rates through the reduction of the amount of long-term assets that the private sector holds (Gagnon et al., 2011; Joyce et al., 2012). The second is the 'signalling' channel through which LSAPs could signal to market participants that the Fed has changed its views on policy preferences. This in turn might change bond investors' expectations of the future short term interest rate resulting in lengthening the period of the near-zero federal fund rate. The 'signalling' channel would decrease long term bond yields by reducing the average expected short-rate which is component of the long term rates (Bauer and Rudebusch, 2013).

\footnotetext{
${ }^{2}$ This theoretical framework, is particularly relevant in the case of LSAPs, in which financial institutions are engaged particularly and thus 'portfolio balance' theory is a core mechanism that could explain the impact of UMP on bank risk (Steeley, 2015). Tobin $(1963,1969)$ suggests that central banks could decrease the relative returns of financial institutions by shifting supplies of assets with different maturities and liquidity due to imperfect substitutability. In particular, when a central bank buys assets from banks, the amount of cash that financial institutions hold increases. Since cash is not a perfect substitute for assets, banks would put emphasis in rebalancing their portfolios by purchasing assets that are better substitutes and offer higher yield (Joyce et al., 2012; Kapetanios et al., 2012). These assets would comprise riskier assets than cash, such as stocks and bonds that in turn would increase the undertaken risk of banks (Fisher, 2010; Fratzscher et al., 2014).
} 
However, the empirical evidence on the effect of UMP on bank profitability is rather scarce. In particular, we know of only two studies that focus on the underlying relationship between UMPs and bank performance (Montecino and Epstein, 2014; Lambert and Ueda, 2014). Montecino and Epstein (2014) find that LSAPs, as proxied by a 'counterparty treatment variable', increase bank profitability but this effect is robust only for the large US banks. Furthermore, Lambert and Ueda (2014) investigate the impact of UMPs, as captured by the central bank's assets over gross domestic product (GDP) ratio, on bank profits for a sample of the US commercial banks over the 2007Q3-2012Q3 period. They find that UMPs exert a negative effect on bank performance and thus they raise questions concerning the effectiveness of expansionary policies on the performance of financial institutions.

These two studies (Montecino and Epstein, 2014; Lambert and Ueda, 2014) do not find a strong positive association between UMPs and bank performance. Unconventional monetary policies took place in the US after the burst of the financial crisis aiming to boost the wider economy, thus when one examines the impact of these policies on bank performance should take into account also the regulation framework that is particularly associated with the deposit runs of banks. In detail, as a response to the financial crisis, numerous countries increased significantly the coverage of their financial safety nets aiming to prevent potential contagion defaults in the banking sector. In particular, a recent study by Anginer et al. (2013) shows that during periods of normal economic conditions, deposit insurance has a negative impact on bank stability, while over periods of economic crisis, deposit insurance coverage exerts a 'stabilization effect' on banks. Therefore, when we examine the relationship between unconventional monetary policy and bank performance, we should also control for the effect of the deposit insurance coverage particularly during economic downturns when contagious bank defaults are more likely to take place.

The paper contributes to the existing literature in several ways. Firstly, we shed new light on the underlying relationship between the UMPs and bank performance as estimated by a number of accounting ratios for a sample of US commercial and saving banks over the 2007Q2-2013Q2 period. Secondly, we test whether the association between UMPs and bank performance varies based on different levels of bank asset diversification and deposit funding. Thirdly, we examine how deposit insurance coverage relates to the performance of banks over this period, while we also test whether the relationship between UMPs and bank performance changes for Federal Deposit Insurance Coverage (FDIC)-insured institutions. Finally, we use a dynamic panel 
threshold methodology to identify possible threshold-effects of UMPs with respect to bank performance over a period of significant structural changes for banking institutions as well as for the entire economy.

Our findings suggest a negative relationship between UMPs, as proxied by central bank's asset and excess reserves, and the US bank performance over the 2007Q2- 2013Q2 period. The cross-sectional variation identification strategy illustrates that the negative association between UMPs and performance is more pronounced for banks of low level of asset diversification and high deposit funding. In addition, the negative relationship between UMPs and bank performance is moderated for the FDIC-insured institutions. Lastly, the dynamic panel threshold analysis demonstrates that the negative association between UMP and bank performance is particularly enhanced above the identified threshold value of UMP that classifies two regimes.

The rest of the paper is structured as follows. Section 2 presents the hypotheses to be tested. Section 3 introduces the data, while section 4 discusses the methodology and the results. Section 5 concludes.

\section{Hypotheses to be tested.}

In this section we develop the three main hypotheses of our study; i) the first tests the relationship between the unconventional monetary policy and bank performance ii) the second examines the association between the deposit insurance coverage and performance iii) while the third looks at the relationship between UMPs and bank performance for deposit insured banks. We test these propositions for a sample of the US commercial and saving banks over the crisis period (2007Q2-2013Q2).

\subsection{Unconventional Monetary Policy and Bank Performance}

The existing literature on the relationship between UMPs and bank performance is rather limited, while there is a large discussion on the impact of monetary policy via interest rates on net interest margins of banking institutions. Following the hypothesis advanced by Samuelson (1945), known as the 'Samuelson effect', changes in interest rates affect bank performance, and more specifically profitability, via their effect on bank's interest margins. In other words, when interest rates are very low, banks' revenues from loans decline, while banks' interest expenses from saving deposits do not decrease to the same extent, because banks' portfolio consist primarily of demand and transaction deposits. Similarly, Hancock (1985) shows that an 
increase in interest rates boosts bank profitability, as lending rate elasticity is larger than the deposit rate elasticity. Trying to bridge a link between UMPs and interest margins is imperative to understand the effect of the non-standard monetary policies on the lending interest rates that banks charge borrowers. It is established in the literature that UMPs, particularly via LSAPs, decrease long term interest rates and thus decrease the difference between the federal fund rate (deposit interest rate) and lending interest rates (Gagnon et al., 2011; Swanson, 2011; Krishnamurthy and Jorgensen, 2011; Fawley and Neely, 2013; Bauer and Rudebusch, 2013). Therefore, due to the documented larger elasticity of the lending rate compared to the deposit rate (Hancock, 1985), the reduction of lending interest rates could consequently lead to a faster decrease in revenues than interest expenses arising from deposits. This in turn would depress net interest margins and affect negatively bank performance.

Furthermore, one of the leading theoretical models for the determination of interest margins is the bank dealership model as developed by Ho and Saunders (1981). According to this model, banks are risk-averse financial intermediaries that face inventory risk which arises from the mismatch between liabilities and assets. This risk has to be compensated via the pure interest spread, the difference between loan and deposit rates. Ho and Saunders (1981) suggest that the interest margin is dependent, among others, on the volatility of interest rates signifying that high interest rate volatility increases interest margins. A subsequent study by McShane and Sharpe (1984) argues that bank's interest margin is positively related to interest rate volatility. In support to the above argument, Maudos and Guevara (2006) confirm empirically a significant positive relationship between interest rate volatility and interest margins. Following previous findings (Krishnamurthy and Jorgensen, 2011; Fawley and Neely, 2013; Bauer and Rudebusch, 2013), UMPs, particularly via LSAPs, decrease lending interest rates. This in turn suggests that the difference between lending and deposit interest rates declines. As a result, when interest rates decrease they tend to converge to zero-low bounds and consequently interest rate volatility reduces. Indeed, Krishnamurthy and Jorgensen (2011) find that UMP decreases interest rate volatility as captured by the implied volatility on swaptions. Therefore, decreases of interest rate volatility over expansionary monetary periods could have a positive association with interest margins and bank profits as in Maudos's and Guevara (2006) study.

Apart from the impact of expansionary monetary policies on interest based income, UMP could also affect the performance of banks through its effect on non-interest income that stems from trading financial assets. Banks include in their portfolio loans and other assets such as 
securities, commodities and derivatives held for trading. On the positive side, central bank purchases might increase asset prices through the 'portfolio balance' channel (Tobin, 1963; Vayanos and Vila, 2009). According to this mechanism, bank managers and investors do not consider cash as a perfect substitute of the MBS and Treasury-bills that bank sell to the Fed. Thus, banks are incentivized to use these cash holdings to purchase high return assets such as equity and bonds (Tobin, 1963; Vayanos and Vila, 2009). This in turn raises the demand of trading assets and their prices and would result in portfolio gains stemming from the trading activities of banking institutions. Also, another view suggests that LSAPs reduce the market uncertainty and boost the market participants' confidence in economic projections (Wright, 2012) that might result in the increase of asset prices (Gambacorta et al., 2014). On the contrary, via the 'signalling' channel the Fed's purchases might indicate that economic and financial prospects would deteriorate and this might have a negative effect on asset prices and bank portfolio gains (Christensen and Rudebusch, 2013).

Another mechanism through which unconventional monetary policy could affect bank performance is through its impact on the funding cost of banks. Banks could benefit from nearzero policy rates that would decrease the cost of deposit funding (Lambert and Ueda, 2014). Turning now to the other form of bank's funding, wholesale funding cost could also be reduced as a result of the unconventional monetary policies. Wholesale financiers discipline banking institutions by charging them with higher interest rates than retail depositors do (Calomiris, 1999). However, the Fed's LSAPs are considered by market participants as injection of cash to depository institutions and an implicit guarantee for the well-functioning of the banking industry (Montecino and Epstein, 2014). In support of this argument, Santos et al. (2014) find that banks benefit from a cost advantage with regards to raising funding in the bond market, as investors believe that they are too big to fail and thus they would discount risk and reduce borrowing cost. Therefore, during non-conventional monetary policies banks could benefit from a reduction in interest rates charged by wholesale financiers. Other studies (Gagnon et al., 2011; Gilchrist and Zakrajsek, 2013), find that banks that issue bonds as a form of long term debt can benefit from lower funding costs as LSAPs decrease bond yields. Additionally, the Fed's purchases of Mortgage Backed Securities (MBS) from depository institutions, suggest that the central bank might have subsidised banks' funding cost to fund these mortgages (Kandrac and Schlusche, 2015). 
Based on the above discussion there is no clear indication of the effect of UMP on bank performance, thus the hypothesis H1.A and the competing proposition H1.B are formed as follows:

H1.A (H1.B): The effect of unconventional monetary policy on bank performance is negative (positive).

\subsection{Deposit Coverage Insurance, UMP and Bank Performance}

To date, the existing literature is inconclusive with regards to the relationship between deposit insurance coverage and bank performance. On the one hand, insured depositors might charge lower deposit rates due to the presence of insurance protection (Peria and Schmukler, 2001; Demirguc-Kunt and Huizinga, 2004). This reduction in deposit rates due to the presence of deposit insurance would lead to lower funding costs and this in turn would increase banks' interest margins (the difference between lending and deposit rates) and thus performance. In the absence of deposit insurance coverage, monitoring of banks by private parties increases and thus uninsured depositors tend to discipline banks by demanding higher deposit rates (Demirguc-Kunt and Kane, 2002; Anginer et al., 2013). Moreover, deposit insurance could also impact the lending rates positively, as bank managers might lend to customers of low creditworthiness suggesting that they would require higher interest rates for the loans provided (Carapella and Giorgio, 2004; Ioannidou and Penas, 2010). This could suggest that deposit insurance coverage might have a positive impact on bank profitability through its effect on interest margins. On the other hand, when deposit insurance is in effect, the relaxation of credit standards and monitoring procedures could result in a higher level of loan losses, thus reducing profits and net interest margins (Abreu and Mendes, 2002).

Based on the above discussion there is no clear indication of the effect of deposit insurance on bank performance, thus the hypothesis H2.A and the competing proposition $\mathrm{H} 2 . \mathrm{B}$ are formed as follows:

H2.A (H2.B): The effect of deposit insurance coverage on bank performance is negative (positive).

Drawing from the arguments in the previous section (2.1), one major channel through which expansionary monetary policy could affect bank performance is through reduction in the interest margins that arises from the decrease in lending rates when the short term rate (fed 
fund rate) is close to the zero lower bound (Fawley and Neely, 2013; Bauer and Rudebusch, 2013). The reduction in net interest margins could be more pronounced for uninsured banks. This is so as uninsured depositors discipline banks by charging higher deposit interest rates (Anginer et al., 2013). On the contrary, if deposits are insured, depositors lack incentives to monitor and consequently charge lower interest rates on deposits (Demirguc-Kunt and Huizinga, 2004). This reduction in interest margins because of the monitoring of depositors could be strengthened for deposit uninsured banks. Moreover, at the presence of lower margins over unconventional monetary policy periods, insured banks are encouraged to relax further their credit standards because of lack of private monitoring and thus increase lending to borrowers of low creditworthiness (Carapella and Giorgio, 2004; Ioannidou and Penas, 2010). However, as discussed earlier, lower credit standards for deposit insured institutions might lead to a higher loan default rate that could result in bank losses (Abreu and Mendes, 2002). In this case, the negative (positive) effect of UMP on performance would be strengthened (moderated) for banks with deposit insurance coverage.

Based on the above discussion hypothesis H3.A and the competing hypothesis H3.B would be formulated as follows:

H3.A The positive (negative) effect of unconventional monetary policy on bank performance is strengthened (moderated) for deposit insured institutions.

And

H3.B: The positive (negative) effect of unconventional monetary policy on bank performance is moderated (strengthened) for deposit insured institutions.

\section{Data and Variables}

We use quarterly financial data from the Fitch IBCA's Bankscope database for a period that covers the financial crisis 2007Q2-2013Q2. Our final sample includes 6771 US commercial and saving banks and a total of 88,888 observations, after removing errors and inconsistencies. Table 1 describes all dependent and explanatory variables employed in the empirical analysis.

\section{[INSERT TABLE 1 ABOUT HERE]}

\subsection{Unconventional monetary policy and deposit insurance coverage variables}


Since 2009, the Fed has conducted numerous LSAPs rounds that include primarily Treasury securities and mortgage-backed securities (MBS). In 2014, the Fed purchased almost \$2.5 and $\$ 1.7$ trillion of Treasury securities and MBS respectively. This had, as a result, the expansion of the Fed's balance sheet by almost five times compared with the size of it before the crisis. Consequently, UMPs, through LSAPs, have increased substantially both the asset and liability side of the Fed's balance sheet. A number of previous studies highlight that the size of central bank's assets is an appropriate measure of UMPs and indeed is found to influence the prices of specific assets in previous studies (Greenwood and Vayanos, 2010; Gagnon et al., 2011; Hamilton and Wu, 2012; D’Amico and King, 2013; Gambacorta et al., 2014), while Lambert and Ueda (2014) demonstrate its significant effect on the profitability of the US banks. Similarly, we use the natural logarithm of central bank's assets (CBA) to capture the expansion of the Fed's balance sheet from the asset side.

Moreover, the expansion of the liability side of the Fed's balance sheet due to the initiation of the LSAPs has led to a significant increase in excess reserves held by banks (Todd, 2013). Excess reserves stand for the extra amount of reserves against deposits and other liabilities that banks hold above the required reserves that the federal law suggests. In particular, excess reserves increased sharply since the late 2008 in the US. In 2007, excess reserves averaged \$1.9 billion, while by April 2014 reached around $\$ 1.863$ trillion, of which only around $\$ 115$ billion are required reserves. This large increase in excess reserves is reflected by its high standard deviation (1.04) over the period under study 2007Q2-2013Q2. Moreover, this substantial growth in excess reserves has also been driven by an important policy change; since 2008 the Fed has started to pay interest on reserves. This, in turn, has encouraged banks to maintain a large amount of excess reserves. In addition, paying interest on reserves allows the central bank to put a floor on the federal funds rate, as banks would be hesitant to lend out their reserves at rates lower than those that they can earn from the Fed (Kozicki et al., 2011). This, in turn, offers the ability to the Open Market Trading Desk, 'the Desk', at the Fed to maintain the federal fund rate very close to the Federal Open Market Committee's (FOMC's) target rate (Federal Reserve Bank of New York, 2013). Therefore, we also use as a second proxy of UMP, the natural logarithm of excess reserves (EXC_RES) as in Bech’s and Monnet (2013) study.

[INSERT TABLE 2 ABOUT HERE] 
Additionally, in order to account for the effect of the deposit insurance coverage, we employ a comprehensive dataset that provides bank-specific information on all the FDIC-insured institutions. Also, it offers valuable evidence on the particular date that a bank has gained access into the FDIC that in turn captures time heterogeneity. ${ }^{3}$ Thus, we include a dummy that takes the value of 1 for those banks (and years) that deposits are insured, while takes the value of 0 for these banks (and years) that do not have access to the FDIC. The increase of deposit insurance coverage is particularly evident the recent years by the mean value of the FDIC dummy variable that is equal to 0.65 , thus, more than the half of our sample includes FDICinsured financial institutions (Table 2).

\subsection{Control Variables}

We employ a number of bank-specific control variables consistent with a number of previous empirical studies. We use the natural logarithm of total assets to proxy for the size of each bank (SIZE). The existing empirical evidence on the relationship between size and bank performance is mixed (Altunbas et al., 2001; DeGuevara and Maudos, 2007). On the one hand, bank size might have a positive relationship with bank performance due to higher diversification benefits (Mester, 1993). On the other hand, according to the literature, bank size could be related negatively with bank performance if economies of scope and scale are not realized. We also include the equity over total assets ratio to account for capital (E/TA), as in previous studies (Athanasoglou et al., 2008; Lepetit et al., 2008). The association between the E/TA ratio with bank performance could be positive, as more capital at risk prompts managers to undertake less risky positions that in turn would protect banks from increased losses (Gorton and Rosen, 1995; Athanasoglou et al., 2008; Lepetit et al., 2008). On the other hand, an increase of leverage, which implies a decrease of capital, might have a positive relationship with bank performance under the 'agency cost' hypothesis introduced by Jensen and Meckling (1976). This is because increases of leverage (decreases of capital) could moderate the conflicts that shareholders and managers have with regards to the risk of an investment choice (Myers, 1977). When leverage increases the priority of managers is to secure funding to pay the debt rather to undertake extremely risky projects (Myers, 1977). Hence, high leverage (low capital) might be correlated positively with bank performance, consistent with Berger and Bonaccorsi di Patti (2006). We also account for the relationship between liquidity, as estimated by the ratio of liquid assets to

\footnotetext{
${ }^{3}$ We would like to thank an anonymous Reviewer for pointing out the necessity to use an informative measure of FDIC that would enable us to capture bank and time heterogeneity. Data for all the FDIC-insured institutions are available here: https://www5.fdic.gov/idasp/warp_download_all.asp.
} 
total assets (LIQ/TA), and bank performance. Previous empirical studies show that the association between liquidity and performance could be positive due to the lower liquidity risk (Demirguc-Kunt and Huizinga, 1999; Athanasoglou et al., 2008). However, there is evidence to suggest that this relationship might be negative since high liquidity might be associated with low returns (Pasiouras and Kosmidou, 2007) and high storage expenses (Kwan, 2003). Furthermore, we opt for the ratio of loans to total assets (LA/TA) consistent with previous studies (Pasiouras, 2008; Lin and Zhang, 2009; Garcia-Herrero et al., 2009; Bertay et al., 2013). Lastly, we also account for the insolvency risk as estimated by the Z-SCORE $=(1+\mathrm{ROE}) / \sigma_{\mathrm{ROE}}$, where ROE is the return on equity and $\sigma_{\mathrm{ROE}}$ is the estimate of standard deviation of ROE (Boyd and Graham, 1986). Higher values of Z-SCORE for a bank indicates higher distance from default and therefore we expect that increases of Z-SCORE would have a positive correlation with bank performance consistent with numerous previous studies (Lepetit et al., 2008; Delis and Staikouras, 2011).

Turning now to the rest of the control variables, we opt for a number of macroeconomic variables to capture the general economic conditions. ${ }^{4}$ Thus, as proxies of macroeconomic stability we include in our regressions gross domestic product growth (GDP gr) and inflation (INFL) consistent with previous studies (Lozano-Vivas and Pasiouras, 2010; Chortareas et al., 2011; Kalyvas and Mamatzakis, 2014). On the one hand, there is empirical evidence to support that favorable economic conditions, i.e. high GDP gr, are related positively with banking expenses owing to higher operating costs to offer a particular level of services (Dietsch and Lozano-Vivas, 2000). Also, banks tend to increase their lending through shifting to riskier assets aiming to rise their returns. This in turn might dampen bank performance in the long run (Delis and Kouretas, 2010). On the other hand, GDP gr might be correlated negatively with banking costs due to the easy access that banks have to new technologies in prosperous countries (Lensink et al., 2008). Lastly, we also include the ratio of non-performing loans to total loans at the US state level (NPLs), in order to capture the state-specific credit risk. ${ }^{5}$

Regarding the relationship between inflation and bank performance, Revell (1979) claims that it depends on whether bank's salaries and other operating expenses could increase at a faster (lower) degree than the inflation rate. Thus, if a bank's management could predict the inflation

\footnotetext{
${ }^{4}$ We would like to thank an anonymous Reviewer who proposed to introduce variables such as GDP growth, inflation and unemployment rate, aiming to capture the effect of general economic conditions on bank performance.

${ }^{5}$ For the state-level non-performing loans ratio we obtained the data from the Federal Reserve Bank of St. Louis.
} 
rate, a bank could adapt interest rates in order to increase revenues faster than costs and hence improve bank performance. In contrast, if bank managers could not accurately predict the inflation rate that would not result in appropriate adjustment of interest rates. In that case, bank costs would increase at a higher level than earnings resulting in the reduction of bank performance. Moreover, we include as another measure of economic conditions the unemployment rate (UEMP). The association between UEMP and bank performance is expected to be negative, consistent with Abreu and Mendes (2002). We also control for the interest rate policy in our regression model, including the federal fund rate (Fed rate). The relationship between the Fed rate and bank performance is expected to be positive. In particular, lower interest rates are positively related with risk-taking (Ioannidou et al., 2009; Brissimis and Delis, 2009; Jimenez et al., 2013) that in turn might dampen bank performance.

\section{Methodology and Results}

\subsubsection{Fixed effect estimator}

As a first step of the empirical analysis we run the following general model with the fixed effect estimator:

$(\text { Perform })_{i, t}=\left[c+a_{1}(U M P)_{t}+a_{2}(D I C)_{i, t}+\sum_{j=1}^{n} \beta_{j}(\text { Control })_{i, t}+v_{i}+u_{i, t}\right]$

where $(\text { Perform })_{i, t}$ is the vector of bank-specific measure of the US bank performance proxied by four different variables; 1) return on assets (ROA), 2) return on equity (ROE), 3) pre-tax operating income as a percentage of the average total assets (POI), 4) and net interest margin (NIM). $c$ is the constant term, $(U M P)_{t}$ stands for the unconventional monetary policy independent variable. $(D I C)_{i, t}$ is a dummy variable that captures the deposit protection and takes the value of 1 for the FDIC-insured banks, otherwise it takes the value of 0 . (Control) $)_{i, t}$ comprises a number of bank-specific, state-level and country-level control variables, $v_{i}$ is the unobserved bank-specific effect, while $u_{i, t}$ denotes the idiosyncratic error term. $a_{1}, a_{2}$ and $\beta_{j}$ are the parameters to be estimated.

Fixed effect estimator is an appropriate method in the context of our study as we use a panel dataset. ${ }^{6}$ In particular, with fixed effect estimation we take into account heterogeneity across banks as it allows unobserved bank-specific characteristics, $v_{i}$, to be arbitrarily correlated with

\footnotetext{
${ }^{6}$ We use the Hausman (Hausman, 1978) test that rejects the null hypothesis, suggesting that the fixed effect estimator (and not random effect) is the preferred estimation method.
} 
the observed explanatory variables (Baltagi, 2008). Therefore, bank fixed effects, $v_{i}$, capture heterogeneity across banks as bank-individual characteristics are not constrained and could impact upon the predictor variables. Fixed effect wipes out the impact of time-invariant characteristics and hence we could examine the underlying relationship between UMPs and the rest of our explanatory variables with bank performance.

\subsubsection{Fixed effect panel results}

The fixed effect estimations reveal that the unconventional monetary policy, as estimated by two different proxies, has a negative relationship with bank performance in support of our H1.A hypothesis. In particular, unconventional monetary policy, as measured by central bank's assets (CBA), has a negative relationship with bank performance across all different performance's measures specifications (ROE, ROA, NIM, POI). In some detail, 1\% increase of CBA is associated with a 0.890 percentage points decrease in ROE. Similar results we observe when we use excess reserves (EXC_RES) as an alternative measure of UMP. Also, the EXC_RES has a negative association with bank performance at the $1 \%$ level across all our regression models (Table 3). Similarly to the CBA specification, if EXC_RES increases by 1\% we expect a 0.707 percentage points decrease in ROE. Mostly, we observe that CBA has a stronger negative association with bank performance compared to that of EXC_RES and performance. Overall, these findings reveal that there is a negative relationship between UMP and bank performance. These results do not identify directly the exact channels through which UMP is related negatively with bank performance. Based on our discussion in the hypotheses section, some potential mechanisms could be in play. Briefly, over the monetary expansionary periods, the deposit rate (federal fund rate) has been kept at zero lower bounds. Also, previous studies find that unconventional monetary policy, through LSAPs, has led to the reduction of lending rates (Krishnamurthy and Jorgensen, 2011; Fawley and Neely, 2013; Bauer and Rudebusch, 2013). Thus, based on that channel, UMP could affect bank performance through the depression on interest margins. Another channel through which UMP could be associated negatively with bank performance is through its effect on bank asset prices. Market participants could regard Fed's purchases as a signal of deterioration of financial prospects which could affect adversely the value of the trading assets and thus the portfolio gains of banks (Christensen and Rudebusch, 2013).

[INSERT TABLE 3 ABOUT HERE] 
Turning to the other variable of our main interest, we observe that federal deposit insurance coverage (FDIC) has a negative relationship with bank performance as estimated by different accounting-based indicators across all our specifications. In some detail, the relationship between deposit insurance coverage and performance is negative and significant at the $1 \%$ level across the majority of our regression models (see Table 3) lending support to the H2.A. This evidence is consistent with the existing literature that loan losses of deposit insured institutions could increase due to relaxed credit standards, thereby increasing costs and depressing interest margins (Abreu and Mendes, 2001).

In addition, we go a step further and investigate the association between the interaction term of UMP and deposit insurance coverage with bank performance. Our results show that the negative relationship between unconventional monetary policy and bank performance, as discussed above, is less pronounced for FDIC-insured financial institutions. In some detail, the interaction of the deposit insurance coverage with the two alternative measures of UMP, CBA*FDIC and EXC_RES*FDIC, enters the regressions positive and significant (Table 3), suggesting that the negative association between UMP and bank performance is moderated for FDIC-insured banks lending support to the H3.A hypothesis. This relationship is more pronounced for those specifications where we employ EXC_RES as a measure of UMP. Overall, our findings show that the negative relationship between UMP and bank performance is somewhat smaller for the FDIC-insured banks. Although our regression model does not detect the exact mechanism through which UMP could be associated positively with performance of FDIC-insured institutions, a potential reason for our result could be that depositors of FDIC-insured banks might lack incentives to monitor banks and thus they charge lower deposit rates compared to that of non-insured depositors (Demirguc-Kunt and Huizinga, 2004).

Turning to the rest of the bank-specific control variables, we find that there is a positive association between size (SIZE) and bank performance as estimated by the ROA, ROE, NIM and POI ratios. Our finding is consistent with previous literature and thus a potential reason for this result could be that bank size could offer diversification benefits through economies of scale and scope (Mester, 1993). In addition, we find that the loans over total assets ratio (LA/TA) has a positive and significant relationship with bank performance at the $1 \%$ significance level (see Table 3). Our results are also consistent with these of previous empirical studies (Isik and Hassan, 2003; Casu and Girardone, 2004; Lensink et al., 2008). 
We also observe that E/TA ratio has a positive relationship with bank performance across all the relevant specifications (see Table 3). More specifically, this relationship is significant at the $1 \%$ level when ROE and ROA are used to proxy for bank performance (see Table 3). Our finding is consistent with the ones of Athanasoglou et al. (2008) and Lepetit et al. (2008). A potential reason for this result could be that high level of bank capitalisation might be associated with profitable managerial positions which could reduce bank losses as explained by Gorton and Rosen (1995). Additionally, we find that LIQ/TA ratio has a negative relationship with bank performance. This evidence conforms with previous studies (Kwan, 2003; Pasiouras and Kosmidou, 2007).

Moreover, we examine the relationship between insolvency risk, as calculated by the ZSCORE, and bank performance. Our findings demonstrate, that there is a positive relationship between the ZSCORE and bank performance at the 1\% significance level (see Table 3). Our empirical results are in line with a number of previous studies (Lepetit et al., 2008; Barry et al., 2011; Delis and Staikouras, 2011). One potential reason for this result, according to the literature, could be that banks with high default risk (lower Z-SCORE) divert resources from day-to-day to monitoring operations that in turn could increase bank expenses and thus reduce banks’ profitability (Berger and DeYoung, 1997). Lastly, we observe that there is a negative relationship between NPLs and bank performance at the 1\% significance level across the majority of our specifications (see Table 3).

Regarding the country-level control variables, we find that GDP growth (GDP gr) has a negative relationship with bank performance consistent with previous studies (Yildirim and Philipatos, 2007; Delis and Kouretas, 2010). A potential reason could be that higher operating expenses to supply a given level of services might be associated with prosperous economic conditions (Dietsch and Lozano-Vivas, 2000). Moreover, we find that inflation (INFL) is related negatively with bank performance in line with previous empirical evidence (Wallich, 1977; Petersen, 1986; Lozano-Vivas and Pasiouras, 2010) and literature which suggests that if bank's management could not accurately predict inflation rate and consequently could not adjust interest rates equivalently, bank expenses increase at a faster pace than revenues suggesting the decrease of bank profits (Revell, 1979). We also observe a negative association between unemployment rate (UEMP) and bank performance as in Abreu's and Mendes (2002) study. Finally, we find a positive and significant relationship between the Fed rate and 
performance consistent with previous studies (Ioannidou et al., 2009; Brissimis and Delis, 2009; Jimenez et al., 2013).

\subsubsection{Dynamic panel estimations}

As a second step, we test our main hypotheses (H1, H2 \& H3) by employing the two-step 'system’ GMM estimator (Arrelano and Bover, 1995; Blundell and Bond, 1998) as in the Lambert's and Ueda (2014) study. The usage of this estimator is appropriate in the context of this study as it accounts for endogeneity issues. ${ }^{7}$ Moreover, the well-documented persistence in bank profits (Goddard et al., 2004) is controlled by the inclusion of the performance lagged dependent variable amongst the rest of the determinants (Athanasoglou et al., 2008). We also follow the finite sample correction introduced by Windmeijer (2005) as the two-step estimates of standard errors tend to be downward biased (Blundell and Bond, 1998).

The dynamic panel model that we use takes the following form:

$(\text { Perform })_{i, t}=\left[c+\varphi(\text { Perform })_{i, t-1}+a_{1}(U M P)_{t}+a_{2}(D I C)_{i, t}+\right.$

$\left.\sum_{j=1}^{n} \beta_{j}(\text { Control })_{i, t}+v_{i}+u_{i, t}\right]$

where (Perform $)_{i, t}$ is the vector of bank-specific measure of the US bank performance as proxied by ROA, ROE, POI and NIM, while (Perform) $)_{i, t-1}$ stands for the lagged performance independent variable. $(U M P)_{t}$ is the variable that captures the unconventional monetary policy. $(D I C)_{i, t}$ is a bank-specific dummy variable that accounts for the deposit protection and takes the value of 1 , while takes the value of 0 for non FDIC-insured institutions. $(\text { Control })_{i, t}$ includes bank-specific, state-level and country-level control variables, $v_{i}$ is the unobserved bank-specific effect, while $u_{i, t}$ denotes the idiosyncratic error term. $\varphi, a_{1}, a_{2}$ and $\beta_{j}$ are the parameters to be estimated.

\subsubsection{Dynamic panel results}

${ }^{7}$ For the 'system' GMM estimation we use Roodman (2006) “xtabond2” specification in Stata. 
Table 4 shows the regression results of the dynamic panel analysis with the central bank's assets and excess reserves, as unconventional monetary policy variables. The suitability of the usage of the two-step ‘system’ GMM estimator is justified by the significant lagged dependent performance variables in all the corresponding models (see Table 4). In addition, with respect to statistical diagnostics, we observe that the second-order autocorrelation in second differences and the Hansen test are insignificant (see Table 4).

\section{[INSERT TABLE 4 ABOUT HERE]}

Similarly to the fixed effect specifications we observe that UMP, as proxied by CBA and EXC_RES, has a negative and significant relationship with bank performance (see Table 4). In some detail, 1\% increase of CBA and EXC_RES is associated with a 0.581 and 0.102 percentage points decrease in ROA respectively. Largely, we find that the negative association between CBA and bank performance is stronger in magnitude compared to that of the performance with EXC_RES. Our evidence lends further support to our fixed effect results. A potential reason for the negative association between UMP and bank performance, given our discussion on the hypotheses section, could be that UMP lead to the reduction of lending rates consistent with previous studies (Krishnamurthy and Jorgensen, 2011; Fawley and Neely, 2013; Bauer and Rudebusch, 2013). Also, we observe a negative relationship between deposit insurance coverage and bank performance. Moreover, the interactions of the deposit insurance coverage with UMP, as calculated by CBA*FDIC and EXC_RES*FDIC, have a positive association with bank performance suggesting that the negative relationship between UMP and bank performance is less pronounced for the FDIC-insured institutions (see Table 4). In addition, we find that the CBA*FDIC has a stronger in magnitude relationship with bank performance compared to the association between EXC_RES*FDIC and performance. Overall, we find supportive evidence of the fixed effect findings.

Regarding the rest of the bank-specific control variables, we observe that the results are consistent with the fixed effect specifications. In some detail, we observe a positive relationship between the SIZE of the bank and performance (see Table 4) consistent with Mester (1993). Furthermore, we find that the LA/TA ratio is positively associated with bank performance (see Table 4), as in the fixed effect specifications and previous empirical evidence (Isik and Hassan, 2003; Casu and Girardone, 2004; Lensink et al., 2008). In addition, consistent with the fixed effect estimator, we find that the ZSCORE has a positive relationship with bank performance across all our models (see Table 4), in line with previous empirical evidence (Lepetit et al., 
2008; Barry et al., 2011; Radic et al., 2012). Finally, we also observe a negative relationship between NPLs and bank performance (see Table 4). Moreover, we find that GDP gr, INFL and UEMP are associated negatively with bank performance as in fixed effect specifications and previous empirical evidence. Finally, the Fed rate enters the regression positive and significant confirming our previous findings (4.1.2).

\subsection{The relationship between UMPs and bank performance for banks of different asset and funding structure.}

In this part, we report findings regarding the relationship between UMP and bank performance, whilst taking into account two main US bank-specific characteristics: i) the asset diversification and ii) the total deposit funding. ${ }^{8}$ We split the sample accordingly: banks below the $25^{\text {th }}$, between the $25^{\text {th }}$ and the $75^{\text {th }}$ percentile and banks above the $75^{\text {th }}$ percentile. So, we employ three models based on these subsamples, banks of the low, medium and high level of asset diversification and deposit funding. ${ }^{9}$

Our main motivation for this analysis arises from the fact that the US banking institutions are well-diversified institutions in terms of both funding and asset structure. Previous empirical evidence suggests that interest based income that stems from loans is less volatile compared to the income that stems from non-interest bearing assets, such as derivatives and securities (see DeYoung and Roland, 2001; Lepetit et al., 2008). Similarly, banks that rely on trading activities experience higher losses compared to financial institutions that focus on traditional banking operations (Brunnermeier et al., 2012). Also, DeJonghe (2010) demonstrates that banks that engage particularly in non-interest based operations are vulnerable to changes in macroeconomic conditions. These findings illustrate that banks of various levels of asset diversification might react differently to changes in the macroeconomic environment, including unconventional monetary policies. Moreover, banks that rely more on non-deposit

\footnotetext{
${ }^{8}$ We would like to thank an anonymous Reviewer for highlighting the importance of asset and funding structure for the US bank performance. We measure asset diversification by using the following formula: asset Diversification=1-|(Net loans - Other earning assets) / Total earning assets|, consistent with Laeven and Levine (2007). For the level of deposit funding we use the ratio of total deposits over total assets as in Beltratti and Stulz (2012). ${ }^{9}$ Note that we sort the data with respect to the first year, opting for measures of asset diversification and deposit
to asset ratio to take into account the intrinsic characteristics of the US banks. In that way, we avoid any
endogeneity issue arising from bank's management decisions driven by the macroeconomic conditions including
non-conventional monetary policies.
} 
funding than deposits could face higher funding costs as wholesale funders could impose enhanced monitoring and could withdraw their financing faster than depositors (DemirgucKunt and Huizinga, 2010). Some studies argue that market funding would affect negatively the stability of financial institutions in the event of liquidity shocks (Adrian and Shin, 2008; Brunnermeier, 2008; Diamond and Rajan, 2009). This is so as banks that rely particularly on deposits are exposed to lower risk of drying-up in liquidity due to explicit (deposit insurance coverage) and implicit government guarantees (Demirguc-Kunt and Huizinga, 2010; 2013). Given that previous findings suggest that differences in funding structure matter, it is important to examine whether there is variability on the relationship between UMP and performance of banks of different funding structure. It is, therefore, of interest to investigate whether the crosssectional variation in the asset diversification and funding structure would affect the association between UMPs and bank performance. We employ a dynamic panel analysis to exploit the cross-sectional variation of our data. ${ }^{10}$ We include time effects in our models implying that we investigate cross-sectional differences of the relationship between UMPs and bank performance eliminating time variations. ${ }^{11}$ This strategy is similar to that of other previous empirical studies that highlight the importance of cross-sectional variation in identifying differences in the relationship between UMPs and bank characteristics (Becker and Ivashina, 2014; Chodorow-Reich, 2014; Foley-Fisher et al., 2014; Bowman et al., 2015).

Table 5 reports that UMP has a negative association with bank performance across all the three different subsamples; banks of low, medium and high level of asset diversification. Thus, across all subsamples we find that UMP is related negatively with bank performance, with the economic significance of this association being similar across banks. Note that there is some variation on the significance level of the observed relationship among the three regression models. In some detail, the interaction of central bank's assets and asset diversification (CBA*ASSETDIV) has a negative and significant relationship with bank performance at 5\% level in the medium and low level of asset diversification banks, and at $10 \%$ in the high level

\footnotetext{
${ }^{10}$ As in the previous sections (4.2.1 and 4.2.2), we use two-step system GMM estimation following Arellano and Bover (1995) and Blundell and Bond (1998) aiming to account for both endogeneity issues and the documented persistence of bank profits (Berger et al., 2000; Goddart et al., 2004; Athanasoglou et al., 2008). We also use a finite sample correction as developed by Widmeijer (2005) as two-step estimates are likely to be downward biased (Blundell and Bond, 1998). Additionally, we use Hansen diagnostic test of overidentifying restrictions and the second order autocorrelation test of residuals introduced by Arellano and Bover (1991).

${ }^{11} \mathrm{We}$ also run the regression including the bank specific and macroeconomic variables (excluding time dummies) and we find qualitatively similar results. These findings are available upon request.
} 
of asset diversification. In particular, 1\% increase of CBA*ASSETDIV leads to a 0.316 and 0.301 percentage points decrease in ROA for the low and medium subsamples and a 0.289 percentage points decrease for banks of high level of asset diversification. A similar picture arises from the regression results where we employ the interaction of excess reserves with asset diversification (EXC_RES*ASSETDIV). The relationship between UMP and performance remains negative across all banks, but it is significant at $1 \%$ and $5 \%$ for banks that fall within the low and medium level of asset diversification respectively. As a consequence, from a statistical standpoint, the negative relationship between UMP and bank performance is somewhat less pronounced for banks of high level of asset diversification. These results are in line with previous studies where UMPs are found to reduce lending rates and thereby to lower the difference between lending and deposit rates (Gagnon et al., 2011; Swanson, 2011; Krishnamurthy and Jorgensen, 2011; Fawley and Neely, 2013; Bauer and Rudebusch, 2013). Given that banks of low and medium asset diversification rely majorly on interest margins for their profitability, a reduction of interest margins would be of importance for the performance of financial institutions as a whole. Although, the relationship between UMP and bank performance remains negative for banks of high level asset diversification, i.e. those of high share of non-interest based activities, it is less pronounced from a statistical standpoint. ${ }^{12}$

\section{[INSERT TABLE 5 ABOUT HERE]}

Turning now to Table 6, we observe that the negative association between the interaction of central bank's assets with deposit to assets ratio (CBA*DEP/TA) and bank performance has higher economic significance compared to the results in Table 5, where asset diversification has been taken into account. Our findings are consistent with previous studies that find that unconventional monetary policy, through LSAPs, is negatively associated with interest rates and thus closely related with deposit-taking activities (Gagnon, et al., 2011; Swanson, 2011; Krishnamurthy and Jorgensen, 2011; Fawley and Neely, 2013; Bauer and Rudebusch, 2013). Table 6 reveals that for banks of high level of deposit funding, that is banks in the subsample

\footnotetext{
${ }^{12}$ Thus, banks of high level of asset diversification would not be statistically affected by UMP as those banks rely on non-interest related assets. As previously discussed in the hypotheses section, UMPs could restore market uncertainty (Bekaert et al., 2013; Roache and Rousset, 2013) and increase asset prices (Gambacorta et al., 2014). Any positive effect of UMP on asset values could also be explained by the portfolio rebalancing theory (Tobin, 1963; Vayanos and Vila, 2009). Based on this theory, banks receive cash from the central bank and use these proceeds to buy trading assets such as securities. This in turn will give rise to the demand of these assets and increase their prices suggesting gains for banks of high level of asset diversification. Thus, those institutions that engage particularly in non-interest based assets are less adversely affected by UMP compared to banks of medium and low asset diversification.
} 
of high level of deposits to total assets ratio, there exists a stronger negative relationship between UMP and performance, as measured by CBA*DEP/TA, both in terms of economic and statistical significance compared to banks of either low or medium level of deposits to total assets ratio. In particular, CBA*DEP/TA has a negative association with performance of banks in low deposit to total assets subsample, but this is significant at $10 \%$. Also, $1 \%$ increase of $\mathrm{CBA} * \mathrm{DEP} / \mathrm{TA}$ is associated with a 0.920 and 0.673 percentage points decrease in ROA for the high and medium subsample and a 0.836 percentage points decrease for the low subsample. In a similar vein, the association between the interaction of excess reserves with the deposit to assets ratio (EXC_RES*DEP/TA) and bank performance is negative and significant at 1\% only for banks in the subsample of high level of deposit to total assets ratio. In the subsample of low deposits to total assets ratio, again, this relationship is significant but only at $10 \%$. Therefore, for banks that rely particularly on wholesale funding this might mitigate the negative relationship between UMP and bank performance. ${ }^{13}$

\section{[INSERT TABLE 6 ABOUT HERE]}

\subsubsection{Dynamic Panel Threshold Model}

As a further step, we opt for a dynamic panel threshold model that enables us to identify any regime shifts due to UMPs. In some detail, we build on the dynamic panel threshold model of Kremer et al. (2013) based on the cross-sectional balanced panel threshold methodology introduced by Hansen (1999). This model identifies changes in coefficients of the main regressors of our interest, whilst it detects thresholds and thereby different regimes endogenously. In addition, the dataset information would allow to reveal if and when there is a break in the data generating process, rather than imposing arbitrarily a structural break in the data as in Klapper and Love (2011) and Anginer et al. (2014). This is of importance as, during the period of our sample, there is a major financial crisis, but to this date, it is not clear when commercial and saving banks were affected by the crisis. Our model identifies thresholds for central bank's assets and excess reserves and their relationship with bank performance over the period of our study (2007Q2-2013Q2). Based on this estimation technique, we would be able

\footnotetext{
${ }^{13} \mathrm{As}$ we discussed in the hypotheses section (2.1 Section), wholesale financiers could charge higher interest rates than retail depositors aiming to discipline banking institutions (Calomiris, 1999). UMPs could restore wholesale financiers' confidence, as injection of cash to depository institutions function as an implicit guarantee for the wellfunctioning of the banking industry (Montecino and Epstein, 2014). This in turn suggests that banks of higher level of wholesale funding than deposit funding could benefit more from a reduction of funding cost over expansionary monetary periods.
} 
to identify the exact date of the structural break, and detect possible shifts (see Hansen 1999; Kremer et al. 2013).

The threshold model takes the following form ${ }^{14}$ :

$\operatorname{perform}_{i, t}=\mu_{i}+\lambda_{1} m_{i, t} I\left(q_{i, t} \leq \gamma\right)+\delta_{1} I\left(q_{i, t} \leq \gamma\right)+\lambda_{2} m_{i, t} I\left(q_{i, t}>\gamma\right)+\varepsilon_{i, t}$

where perform $i, t$ is the dependent variable and stands for the ROA. $\mu_{i}$ is the bank-specific fixed effect, while $\lambda_{1}$ and $\lambda_{2}$ stand for the two reverse regression slopes based on the assumption that there exist two regimes, $\varepsilon_{i t}$ is the random error. $m_{i t}$ is a vector of explanatory variables that include bank-specific, state-level and country-level control variables. $\delta_{1}$ is the regime dependent intercept as introduced by Bick (2007) and its inclusion is essential for estimating both the threshold value and the coefficient magnitudes of the two regimes. $I$ stands for the indicator function suggesting the regime specified by the threshold variable $q_{i t}$ and the threshold value $\gamma$.

The $\varepsilon_{i, t}^{*}$ takes the following transformation:

$\varepsilon_{i, t}^{*}=\sqrt{\frac{T-t}{T-t+1}}\left[\varepsilon_{i, t}-\frac{1}{T-t}\left(\varepsilon_{i(t+1)}+\cdots+\varepsilon_{i, T}\right)\right]$

In the equation (3) the threshold variable is $q_{i t}$, and herein refers to the two measures of unconventional monetary policy; i) central bank's assets and ii) excess reserves. $\gamma$ is the threshold value which would indicate those observations above (high regime) and below the threshold value (low regime). The above dynamic panel threshold model employs a GMM estimation method (see Arellano and Bover, 1995; Caner and Hansen, 2004) so as to address issues related to endogeneity and avoid the serial correlation in the transformed errors.

The estimation of the threshold variable follows a two-step procedure; in the first step, the estimation of a reduced type regression for the endogenous variable as a function of instruments takes place. The predicted values are then used to replace the endogenous variable in the equation (3). Next, we estimate equation (3) for a fixed threshold value where the threshold variable is replaced by its predicted values obtained in the first step. Threshold values are then specified by the minimization of the concentrated sum of squared errors as $\gamma_{i}^{*}=\operatorname{argmin}_{\gamma} S_{i(\gamma)}$

\footnotetext{
${ }^{14}$ For simplicity we outline the threshold model based on two identified regimes and one threshold. Without loss of generality, this model could expand to more thresholds and thereby more regimes.
} 
(Chan, 1993; Hansen, 1997). Lastly, slope coefficients $\lambda_{1}$ and $\lambda_{2}$ could be estimated with the usage of the GMM estimator (Caner and Hansen, 2004).

\subsubsection{Dynamic threshold results}

If a central bank intends to initiate higher levels of UMPs, through more LSAPs, bank investors are more easily persuaded about the future policies of the central bank and thus their beliefs that interest rates would remain low for a long period become stronger (Bernanke et al., 2004). Eggertson and Woodford (2003) suggest that UMPs could prove to be beneficial in decreasing bond yields only if these policies function as a credible commitment by the central bank to retain interest rates low. Clouse et al. (2003) suggest that this commitment becomes more credible if central bank purchases large volumes of MBS and Treasury bills. In particular, Bauer and Rudebusch (2013) find that a LSAP announcement results in the lengthening of the expected period of near-zero policy rates. The reason is that if a central bank decides to increase interest rates then it would have a loss on these assets (Krishnamurthy and Vissing-Jorgensen, 2011).

Therefore, if a central bank purchases large quantities of long term assets this signals a credible commitment that interest rates would be low for a rather longer period of time. This, however, could induce bank managers to decrease their lending standards. It is evident in the existing literature that low interest rates for a prolonged time soften lending standards (Adrian and Shin, 2010; Maddaloni and Peydro, 2011), suggesting that banks tend to lend credit to borrowers of low creditworthiness. This could suggest an increase in problem loans, resulting in the increase of bank losses (Abreu and Mendes, 2001). Thus, the negative relationship between UMPs and bank performance would be pronounced at higher levels of UMPs. Moreover, lower interest rates, as discussed in the hypotheses section, decrease the difference between the long and short term interest rates, i.e., interest margins (Gagnon, et al., 2011; Swanson, 2011; Krishnamurthy and Jorgensen, 2011; Fawley and Neely, 2013; Bauer and Rudebusch, 2013). Therefore, since larger volumes of LSAPs signal longer duration of near-zero interest rates, the negative relationship between UMPs and banks’ interest margins would be pronounced at higher levels of UMPs in quantitative terms.

Our results in the fixed effect and dynamic panel regressions indicate the presence of a negative relationship between UMPs and bank performance. Based on these first results and the discussion above, we believe that the negative association between UMPs and bank performance would be more pronounced for larger volumes of UMPs compared to that of lower 
quantities of UMPs. Thus, we implement the dynamic panel threshold model introduced by Kremer et al. (2013) which allow us to identify the presence of potential threshold-effects of the unconventional monetary policy with respect to the US bank performance. The potential presence of threshold-effects would enable us to research in depth a period of significant structural changes for banking institutions. We employ this econometric method by setting as threshold variables two alternative UMPs measures, CBA and EXC_RES.

\subsubsection{Threshold variable Central bank assets}

Our dynamic threshold analysis reveals a threshold value of the CBA to be 5.560105 (see Table 7). This value splits the sample of 82,117 observations into two regimes. The high regime includes all the observations whereby the level of the CBA, is above the 5.560105. By contrast, in the low regime belong all these observations for which the value of CBA is below 5.560105 . Our findings suggest that the CBA has a negative relationship with bank performance for both regimes. In particular, coefficient estimates on the association between UMPs and bank performance are $\lambda_{2}=-4.075$ for the high regime and $\lambda_{1}=-2.548$ for the low regime (see Table 7). In some detail, we observe that the CBA has a stronger, in terms of magnitude, relationship with bank performance for banks that belong to the high regime compared to those that belong to the low regime. Also, 1\% increase of CBA is associated with 4.075 (high regime) and 2.548 (low regime) percentage points decrease in ROE. Thus, our findings lend support to our expectations that the negative relationship between UMP and bank performance would be more pronounced under higher levels of the Fed's asset purchases.

\section{[INSERT TABLE 7 ABOUT HERE]}

Likewise, we also observe a negative association between LIQ/TA and NPLs and bank performance. In addition, we find a positive association between FDIC-insured institutions and bank performance. We also find that both Z-SCORE and E/TA ratio are associated positively with bank performance. Moreover, consistent with our previous findings GDP gr, INFL and UNEMP are related negatively with bank performance. Finally, we find that the Fed rate has a positive and significant relationship with bank performance.

Moreover, Figure 1 illustrates that the initiation of unconventional expansionary policies is evident particularly in the third quarter of 2008, whereby the level of CBA was increased considerably compared to that of the previous period (2007Q2-2008Q2). In addition, we 
observe that the magnitude of the negative relationship between UMPs and bank performance in the high regime refers to the 2011Q1-2013Q2 period, suggesting that the destabilizing relationship between UMP and bank performance is more pronounced in this period.

\section{[INSERT FIGURE 1 ABOUT HERE]}

\subsubsection{Threshold variable Excess Reserves}

Our dynamic threshold analysis reveals a threshold value of the EXC_RES to be 13.9947 (see Table 8). This value splits the sample of 82,117 observations into two regimes. The high regime comprises all these observations where the EXC_RES is above the 13.9947. On the contrary, the low regime includes the rest observations for which the EXC_RES takes values below the threshold value, i.e., 13.9947. Our results show that the EXC_RES has a negative relationship with bank performance for both regimes consistent with the previous section (4.4.3). In particular, we observe that in the high regime EXC_RES is associated negatively with bank performance, as $\lambda_{2}=-3.368$, at the $1 \%$ significance level (see Table 8). Similarly, our findings show that in the low regime EXC_RES is related negatively with bank performance, as $\lambda_{1}=-$ 0.428 , at the $1 \%$ level of significance. Moreover, we observe that the negative relationship between EXC_RES and performance is stronger in magnitude for the higher regime $\left(\lambda_{2}=\right.$ 3.368 ) compared to that of the lower $\left(\lambda_{1}=-0.428\right)$, confirming our previous findings (4.4.3). In addition, 1\% increase of EXC_RES is associated with 3.368 and 0.428 percentage points decrease in ROE for the high and low regime respectively.

\section{[INSERT TABLE 8 ABOUT HERE]}

Moreover, regarding the rest of the variables results are similar to the fixed effect and dynamic panel specifications. We find E/TA, SIZE, LA/TA and Z-SCORE have a positive relationship with bank performance. In contrast, LIQ/TA, FDIC, NPLs, GDP gr, INFL and UEMP have a negative association with bank performance. Finally, we observe that Fed rate and EXC_RES*FDIC enter the regression significant and positive.

Turning now to Figure 2, we observe a huge growth of the level of excess reserves during the period under study. Notably, the level of excess reserves in 2007Q2 is almost half of it in 2008Q3, indicating that the UMP has led to a significant increase of the EXC_RES. Likewise, 
we observe that the change in the magnitude of the negative relationship between UMP and bank performance occurs around the 2010Q4. This illustrates that the negative association between UMP and bank performance is particularly evident between 2011Q1 and 2013Q2 when excess reserves are considerably high.

\section{[INSERT FIGURE 2 ABOUT HERE]}

\section{Conclusion}

Our results demonstrate that the unconventional monetary policy has a negative relationship with the performance of commercial and saving banks in the US over the 2007Q2-2013Q2 period. This relationship is less pronounced for banks with a high level of asset diversification and low deposit funding. We also find that the observed negative association between unconventional monetary policy and performance is further enhanced for deposit uninsured financial institutions. Additionally, the dynamic panel threshold analysis further reveals that the negative relationship between unconventional monetary policy and bank performance is pronounced above a reported threshold value.

With regards to policy implications, our findings suggest that the Fed should enhance its attention on bank performance while bank managers and supervision should also take into account unconventional monetary policy consequences. Along these lines bank supervision should be reinforced so as to closely monitor bank performance's response to unconventional monetary policies, particularly for banks with a low level of asset diversification and those that rely on deposits, and use this as feedback to the Fed's decision making. 


\section{References}

Abreu, M., and V. Mendes. (2002). Commercial Bank Interest Margins and Profitability: Evidence from EU Countries. Porto Working Paper Series, CISEP, Portugal

Adrian, T., and Shin, H. (2008). Liquidity, monetary policy, and financial cycles. Current issues in economics and finance, 14, Federal Reserve Bank of New York.

Adrian, T., and Shin, H. (2010). Liquidity and leverage. Journal of Financial Intermediation, 19, pages 418-437.

Altunbas, Y., Gambacorta, L., and Marques-Ibanez, D. (2012). Do bank characteristics influence the effect of monetary policy on bank risk?. Economics Letters, 117, pages 220-222.

Altunbas, Y., Gardener, E., Molyneux, P., and Moore, B. (2001). Efficiency in European banking. European Economic Review, 45, pages 1931-1955.

Anginer, D., Demirguc-Kunt, A., and Zhu, M. (2014). How does deposit insurance affect bank risk? Evidence from the recent crisis. Journal of Banking and finance, 48, pages 312-321.

Arellano, M., and Bond, S. (1991). Some tests of specification for panel data: Monte Carlo evidence and an application to employment equations. The Review of Economic Studies, 58, pages 277-297.

Arellano, M., and Bover, O. (1995). Another look at the instrumental-variable estimation of error components models. Journal of Econometrics, 68, pages 29-52.

Athanasoglou, P., Brissimis, S., and Delis, M. (2008). Bank-specific, industry-specific and macroeconomic determinants of bank profitability. Journal of International financial Markets, Institutions and Money, 18, pages 121-136.

Baltagi, B. (2008). Econometric analysis of panel data (Vol. 1). John Wiley and Sons.

Barth, J., Lin, C., Ma, Y., Seade, J., and Song, F. (2013). Do bank regulation, supervision and monitoring enhance or impede bank efficiency?. Journal of Banking and Finance, 37, pages 2879-2892.

Bauer, M., and Rudebusch, G. (2013). Monetary policy expectations at the zero lower bound. Federal Reserve Bank of San Francisco Working Paper, 18. 
Bech, M., and Monnet, C. (2013). The Impact of unconventional monetary policy on the overnight interbank market. In Liquidity and Funding Markets, RBA Annual Conference Volume. Reserve Bank of Australia.

Beck, T., De Jonghe, O., and Schepens, G. (2013). Bank competition and stability: crosscountry heterogeneity. Journal of Financial Intermediation, 22, pages 218-244.

Becker, B., and Ivashina, V. (2014). Reaching for yield in the bond market. The Journal of Finances Letters, 118, pages 135-138.

Bekaert, G., Hoerova, M., and Duca, M. (2013). Risk, uncertainty and monetary policy. Journal of Monetary Economics, 60, pages 771-788.

Beltratti, A., and Stulz, R. (2012). The credit crisis around the globe: Why did some banks perform better?. Journal of Financial Economics, 105, pages 1-17.

Berger, A., and Bonaccorsi di Patti, E. (2006). Capital structure and firm performance: A new approach to testing agency theory and an application to the banking industry. Journal of Banking and Finance, 30, pages 1065-1102.

Berger, A., and DeYoung, R. (1997). Problem loans and cost efficiency in commercial banks. Journal of Banking and Finance, 21, pages 849-870.

Bernanke, B., and Reinhart, V. (2004). Conducting monetary policy at very low short-term interest rates. American Economic Review, 94, pages 85-90.

Bertay, C., Demirguc-Kunt, A., and Huizinga, H. (2013). Do we need big banks? Evidence on performance, strategy and market discipline. Journal of Financial Intermediation, 22, pages 532-558.

Bick, A. (2007). Pitfalls in panel threshold models: The role of regime dependent intercepts. Working Paper, Goethe University.

Blundell, R., and Bond, S. (1998). Initial conditions and moment restrictions in dynamic panel data models. Journal of Econometrics, 87, pages 115-143.

Borio, C., and Zhu, H. (2012). Capital regulation, risk-taking and monetary policy: a missing link in the transmission mechanism?. Journal of Financial Stability, 8, pages 236-251.

Bowman, D., Londono, J., and Sapriza, H. (2015). US unconventional monetary policy and transmission to emerging market economies. Journal of International Money and Finance, 55, pages 27-59.

Boyd, J., and Graham, S. (1986). Risk, regulation, and bank holding company expansion into nonbanking. Quarterly Review, 4, pages 2-17.

Boyd, J., and Graham, S. (1986). Risk, regulation, and bank holding company expansion into nonbanking. Federal Reserve Bank of Minneapolis, Quarterly Review, 10, pages 2-17.

Brissimis, S., and Delis, M. (2009). Identification of a loan supply function: A cross-country test for the existence of a bank lending channel. Journal of International Financial Markets, Institutions and Money, 19, pages 321-335. 
Brunnermeier, M. (2008). Deciphering the liquidity and credit crunch 2007-08. National Bureau of Economic Research. (No. w14612)

Brunnermeier, M., Dong, G., and Palia, D. (2012). Banks’ non-interest income and systemic risk. In AFA 2012 Chicago Meetings Paper.

Buch, C., Eickmeier, S., and Prieto, E. (2014). In search for yield? Survey-based evidence on bank risk taking. Journal of Economic Dynamics and Control, 43, pages 12-30.

Calomiris, C., and Kahn, C. (1996). The efficiency of self-regulated payments systems: Learning from the Suffolk System. National Bureau of Economic Research. (No. w5442)

Caner, M., and Hansen, B. (2004). Instrumental variable estimation of a threshold model. Econometric Theory, 20, pages 813-843.

Carapella, F., and Di Giorgio, G. (2004). Deposit insurance, institutions, and bank interest rates. Transition Studies Review, 11, pages 77-92.

Casu, B., and Girardone, C. (2004). Financial conglomeration: efficiency, productivity and strategic drive. Applied Financial Economics, 14, pages 687-696.

Chang, H., and Song, F. (2014). The Unconventional Effects of Large-scale Asset Purchases: A Firm-level Analysis. Working paper.

Chen, H., Curdia, V., and Ferrero, A. (2012). The Macroeconomic Effects of Large-scale Asset Purchase Programmes. The Economic Journal, 122, pages F289-F315.

Chernykh, L., and Cole, R. (2011). Does deposit insurance improve financial intermediation? Evidence from the Russian experiment. Journal of Banking and Finance, 35, pages 388-402.

Chodorow-Reich, G. (2014). Effects of unconventional monetary policy on financial institutions. National Bureau of Economic Research. (No. w20230).

Chortareas, G., Garza-Garcia, J., and Girardone, C. (2011). Banking sector performance in Latin America: market power versus efficiency. Review of Development Economics, 15, pages 307-325.

Christensen, J., and Rudebusch, G. (2013). Modeling yields at the zero lower bound: Are shadow rates the solution?. Working paper.

Clark, T., Dick, A., Hirtle, B., Stiroh, K., Williams, R., 2007. The role of banking in the US banking industry: risk, return and industry structure. Economic Policy Review, Federal Reserve Bank New York, 13, 39-56.

Clouse, J., Henderson, D., Orphanides, A., Small, D., and Tinsley, P. (2003). Monetary policy when the nominal short-term interest rate is zero. Topics in Macroeconomics.

D’Amico, S., and King, T. (2013). Flow and stock effects of large-scale treasury purchases: Evidence on the importance of local supply. Journal of Financial Economics, 108, pages 425448. 
D’Amico, S., English, W., López-Salido, D., and Nelson, E. (2012). The Federal Reserve's Large-scale Asset Purchase Programmes: Rationale and Effects. The Economic Journal, 122, pages 415-446.

De Guevara, J., and Maudos, J. (2007). Explanatory factors of market power in the banking system. The Manchester School, 75, pages 275-296.

De Jonghe, O. (2010). Back to the basics in banking? a micro-analysis of banking system stability. Journal of Financial Intermediation, 19, pages 387-417.

Delis, M., and Kouretas, G. (2011). Interest rates and bank risk-taking. Journal of Banking and Finance, 35, pages 840-855.

Delis, M., and Staikouras, P. (2011). Supervisory effectiveness and bank risk. Review of Finance, 15, pages 511-543.

Delis, M., Hasan, I., and Mylonidis, N. (2011). The risk-taking channel of monetary policy in the USA: Evidence from micro-level data. MPRA Paper. (No. w34084).

Dell' Ariccia, G., and Marquez, R. (2006). Lending booms and lending standards. The Journal of Finance, 61, pages 2511-2546.

Demirguc-Kunt, A., and Huizinga, H. (1999). Determinants of commercial bank interest margins and profitability: some international evidence. The World Bank Economic Review, 13, pages 379-408.

Demirguc-Kunt, A., and Huizinga, H. (1999). Market discipline and financial safety net design. World Bank Policy Research Working Paper.

Demirguc-Kunt, A., and Huizinga, H. (2004). Market discipline and deposit insurance. Journal of Monetary Economics, 51, pages 375-399.

Demirguc-Kunt, A., and Huizinga, H. (2010). Bank activity and funding strategies: The impact on risk and returns. Journal of Financial Economics, 98, pages 626-650.

Demirguc-Kunt, A., and Huizinga, H. (2013). Are banks too big to fail or too big to save? International evidence from equity prices and CDS spreads. Journal of Banking and Finance, 37, pages 875-894.

Demirguc-Kunt, A., and Kane, E. (2002). Deposit insurance around the globe: Where does it work?. Journal of Economic Perspectives, 16, pages 175-195.

DeYoung, R., and Roland, K. (2001). Product mix and earnings volatility at commercial banks: Evidence from a degree of total leverage model. Journal of Financial Intermediation, 10, pages 54-84.

Diamond, D., and Dybvig, P. (1983). Bank runs, deposit insurance, and liquidity. Journal of Political Economy, 91, pages 401-419.

Diamond, D., and Rajan, R. (2009). The credit crisis: Conjectures about causes and remedies. National Bureau of Economic Research. (No. w14739). 
Dietsch, M., and Lozano-Vivas, A. (2000). How the environment determines banking efficiency: A comparison between French and Spanish industries. Journal of Banking and Finance, 24, pages 985-1004.

Eggertsson, G., and Woodford, M. (2003). Optimal monetary policy in a liquidity trap. National Bureau of Economic Research. (No. w9968).

Fawley, B., and Neely, C. (2013). Four stories of quantitative easing. Federal Reserve Bank of St. Louis Review, 95(January/February 2013).

Fisher, P. (2010). An unconventional journey: the Bank of England's asset purchase programme. London: Bank of England).

Flannery, M. (1981). Market interest rates and commercial bank profitability: An empirical investigation. The Journal of Finance, 36, pages 1085-1101.

Foley-Fisher, N., Ramcharan, R., and Yu, E. (2014). The Impact of Unconventional Monetary Policy on Firm Financing Constraints: Evidence from the Maturity Extension Program. Available at SSRN 2537958.

Fratzscher, M., Duca, M., and Straub, R. (2014). ECB Unconventional Monetary Policy Actions: Market Impact, International Spillovers and Transmission Channels. International Monetary Fund.

Fu, X., Lin, Y., and Molyneux, P. (2014). Bank competition and financial stability in Asia Pacific. Journal of Banking and Finance, 38, pages 64-77.

Fungacova, Z., Solanko, L., and Weill, L. (2014). Does competition influence the bank lending channel in the euro area? Journal of Banking and Finance, 49, pages 356-366.

Gagnon, J., Raskin, M., Remache, J., and Sack, B. (2011). The financial market effects of the Federal Reserve's large-scale asset purchases. International Journal of Central Banking, 7, pages 3-43.

Gambacorta, L., Hofmann, B., and Peersman, G. (2014). The Effectiveness of Unconventional Monetary Policy at the Zero Lower Bound: A Cross-Country Analysis. Journal of Money, Credit and Banking, 46, pages 615-642.

Garcia-Herrero, A., Gavilá, S., and Santabárbara, D. (2009). What explains the low profitability of Chinese banks? Journal of Banking and Finance, 33, pages 2080-2092.

Gatev, E., and Strahan, P. (2006). Banks' advantage in hedging liquidity risk: Theory and evidence from the commercial paper market. The Journal of Finance, 61, pages 867-892.

Gilchrist, S., and Zakrajsek, E. (2013). The Impact of the Federal Reserve's Large-Scale Asset Purchase Programs on Corporate Credit Risk. Journal of Money, Credit and Banking, 45, pages 29-57.

Goddard, J., Molyneux, P., and Wilson, J. (2004). The profitability of European banks: a crosssectional and dynamic panel analysis. The Manchester School, 72, pages 363-381.

Gorton, G., and Rosen, R. (1995). Corporate control, portfolio choice, and the decline of banking. The Journal of Finance, 50, pages 1377-1420. 
Greenwood, R., and Vayanos, D. (2010). Price pressure in the government bond market. The American Economic Review, 100, pages 585-590.

Gropp, R., and Vesala, J. (2004). Deposit insurance, moral hazard and market monitoring. Review of Finance, 8, pages 571-602.

Hamilton, J., and Wu, J. (2012). The effectiveness of alternative monetary policy tools in a zero lower bound environment. Journal of Money, Credit and Banking, 44, pages 3-46.

Hancock, D. (1985). Bank profitability, interest rates, and monetary policy. Journal of Money, Credit and Banking, 17, pages 189-202.

Hancock, D., and Passmore, S. (2014). How the Federal Reserve's Large-Scale Asset Purchases (LSAPs) Influence Mortgage-Backed Securities (MBS) Yields and US Mortgage Rates.

Hansen, B. (1997). Inference in TAR models. Studies in Nonlinear Dynamics and Econometrics, 2, pages 1-14.

Hansen, B. (1999). Threshold effects in non-dynamic panels: estimation, testing and inference. Journal of Econometrics, 93, pages 345-368.

Hausman, J. (1978). Specification tests in econometrics. Econometrica, 46, pages 1251-1271.

Ho, T., and Saunders, A. (1981). The determinants of bank interest margins: theory and empirical evidence. Journal of Financial and Quantitative analysis, 16, pages 581-600.

Ioannidou, V., and Penas, M. (2010). Deposit insurance and bank risk-taking: Evidence from internal loan ratings. Journal of Financial Intermediation, 19, pages 95-115.

Ioannidou, V., Ongena, S., and Peydro, J. (2015). Monetary policy, risk-taking, and pricing: Evidence from a quasi-natural experiment. Review of Finance, 19, pages 95-144.

Isik, I., and Hassan, M. (2003). Financial deregulation and total factor productivity change: An empirical study of Turkish commercial banks. Journal of Banking and Finance, 27, pages 14551485.

Jensen, M., and Meckling, W. (1976). Theory of the firm: Managerial behavior, agency costs and ownership structure. Journal of Financial Economics, 3, pages 305-360.

Jiménez, G., Lopez, J., and Saurina, J. (2013). How does competition affect bank risk-taking?. Journal of Financial Stability, 9, pages 185-195.

Joyce, M., Miles, D., Scott, A., and Vayanos, D. (2012). Quantitative Easing and Unconventional Monetary Policy-an Introduction. The Economic Journal, 122, pages 271-288.

Kalyvas, A., and Mamatzakis, E. (2014). Does business regulation matter for banks in the European Union?. Journal of International Financial Markets, Institutions and Money, 32, pages 278-324.

Kandrac, J., and Schlusche, B. (2015). An agency problem in the MBS market and the solicited refinancing channel of large-scale asset purchases. Working paper.

Kapetanios, G., Mumtaz, H., Stevens, I., and Theodoridis, K. (2012). Assessing the Economywide Effects of Quantitative Easing. The Economic Journal, 122, pages 316-347. 
Klapper, L., and Love, I. (2011). The impact of the financial crisis on new firm registration. Economics Letters, 113, pages 1-4.

Kozicki, S., Santor, E., and Suchanek, L. (2011). Central bank balance sheets and long-term forward rates. Interest Rates, Prices and Liquidity. Working paper, Bank of Canada.

Kremer, S., Bick, A., and Nautz, D. (2013). Inflation and growth: new evidence from a dynamic panel threshold analysis. Empirical Economics, 44, pages 861-878.

Krishnamurthy, A., and Vissing-Jorgensen, A. (2011). The effects of quantitative easing on interest rates: channels and implications for policy. National Bureau of Economic Research. (No. w17555).

Kwan, S. (2003). Operating performance of banks among Asian economies: An international and time series comparison. Journal of Banking and Finance, 27, pages 471-489.

Laeven, L., and Levine, R. (2007). Is there a diversification discount in financial conglomerates?. Journal of Financial Economics, 85, pages 331-367.

Lambert, F., and Ueda, K. (2014). The Effects of Unconventional Monetary Policies on Bank Soundness. International Monetary Fund. No. 14-152.

Lensink, R., Meesters, A., and Naaborg, I. (2008). Bank efficiency and foreign ownership: Do good institutions matter?. Journal of Banking and Finance, 32, pages 834-844.

Lepetit, L., Nys, E., Rous, P., and Tarazi, A. (2008). Bank income structure and risk: An empirical analysis of European banks. Journal of Banking and Finance, 32, pages 1452-1467.

Lin, X., and Zhang, Y. (2009). Bank ownership reform and bank performance in China. Journal of Banking and Finance, 33, pages 20-29.

Lozano-Vivas, A., and Pasiouras, F. (2010). The impact of non-traditional activities on the estimation of bank efficiency: international evidence. Journal of Banking and Finance, 34, pages 1436-1449.

Maddaloni, A., and Peydro, J. (2011). Bank risk-taking, securitization, supervision, and low interest rates: Evidence from the Euro-area and the US lending standards. Review of Financial Studies, 24, pages 2121-2165.

Matutes, C., and Vives, X. (2000). Imperfect competition, risk taking, and regulation in banking. European Economic Review, 44, pages 1-34.

Maudos, J., and Fernandez de Guevara, J. (2006). Banking competition, financial dependence and economic growth.

McShane, R. and Sharpe, I. (1985). A time Series/Cross Section Analysis of the Determinants of Australian Trading Bank Loan/Deposit Interest Margins. Journal of Banking and Finance, 9, pages 155-136.

Mester, L. (1993). Efficiency in the savings and loan industry. Journal of Banking and Finance, 17 , pages 267-286. 
Miles, D. (2014). Inflation, Employment, and Monetary Policy: Objectives and Outcomes in the UK and US Compared. Journal of Money, Credit and Banking, 46, pages 155-167.

Miller, S., and Noulas, A. (1997). Portfolio mix and large-bank profitability in the USA. Applied Economics, 29, pages 505-512.

Montecino, J., and Epstein, G. (2014). Have Large Scale Asset Purchases Increased Bank Profits?. Institute for New Economic Thinking. Working Paper Series.

Myers, S. (1977). Determinants of corporate borrowing. Journal of Financial Economics, 5, pages 147-175.

Pasiouras, F. (2008). International evidence on the impact of regulations and supervision on banks' technical efficiency: an application of two-stage data envelopment analysis. Review of Quantitative Finance and Accounting, 30, pages 187-223.

Pasiouras, F., and Kosmidou, K. (2007). Factors influencing the profitability of domestic and foreign commercial banks in the European Union. Research in International Business and Finance, 21, pages 222-237.

Peria, M., and Schmukler, S. (2001). Do depositors punish banks for bad behavior? Market discipline, deposit insurance, and banking crises. The Journal of Finance, 56, pages 1029-1051.

Petersen, W. (1986). The effects of inflation on bank profitability. Recent Trends in Commercial Bank Profitability. Working paper.

Rajan, R. (2005). Has financial development made the world riskier?. National Bureau of economic Research.

Revell, J. (1979). Inflation and Financial Institutions. Financial Times Limited.

Roache, S. , and Rousset, M. (2013). Unconventional monetary policy and asset price risk. IMF working paper.

Rogers, J., Scotti, C., and Wright, J. (2014). Evaluating asset-market effects of unconventional monetary policy: a multi-country review. Economic Policy, 29, pages 749-799.

Samuelson, P. (1945). The effect of interest rate increases on the banking system. The American Economic Review, 35, pages 16-27.

Santos J. (2014). Evidence from the bond market on banks' too-big-to-fail subsidy. Economic Policy Review, 20, No.2.

Steeley, J., and Matyushkin, A. (2015). The effects of quantitative easing on the volatility of the gilt-edged market. International review of financial analysis, 37, pages 113-128.

Stein, Jeremy C., 2012, "Evaluating Large-Scale Asset Purchases,” Speech delivered at the Brookings Institution, October 11.

Stiroh, K. (2004). Diversification in banking: Is noninterest income the answer?. Journal of Money, Credit and Banking, 36, pages 853-882.

Svensson, L. (2014). How to Weigh Unemployment Relative to Inflation in Monetary Policy? Journal of Money, Credit and Banking, 46, pages 183-188. 
Swanson, E., and Williams, J. (2014). Measuring the effect of the zero lower bound on medium-and longer-term interest rates. National Bureau of Economic Research. (No. w20486).

Tobin, J. (1963). An essay on the principles of debt management. Cowles Foundation for Research in Economics at Yale University.

Tobin, J. (1969). A general equilibrium approach to monetary theory. Journal of money, credit and banking, 1, pages 15-29.

Todd, W. (2013). The Problem of Excess Reserves, Then and Now. Levy Economics Institute of Bard College Working Paper.

Vayanos, D., and Vila, L. (2009). A preferred-habitat model of the term structure of interest rates. National Bureau of Economic Research. (No. w15487).

Wallich, H. (1977). Inflation is destroying bank earnings and capital adequacy. Bankers Magazine, Autumn, pages 12-16.

Williams, M. (2004). Government Cash Management: Good and Bad Practice. World Bank Technical Note.

Windmeijer, F. (2005). A finite sample correction for the variance of linear efficient two-step GMM estimators. Journal of Econometrics, 126, pages 25-51.

Wright, J. (2012). What does Monetary Policy do to Long-term Interest Rates at the Zero Lower Bound?. The Economic Journal, 122, pages 447-466.

Yildirim, H., and Philippatos, G. (2007). Efficiency of banks: Recent evidence from the transition economies of Europe, 1993-2000. The European Journal of Finance, 13, pages 123143. 


\section{List of Tables}

Table 1. Variables Definition and Sources

\begin{tabular}{|c|c|c|}
\hline Notation & Measure & Data source \\
\hline \multicolumn{3}{|l|}{ A. Dep. Variables } \\
\hline Return on assets (ROA) & Total bank profits before tax/ total assets & Bankscope \\
\hline Return on equity (ROE) & Return on equity/ total assets & Bankscope \\
\hline Net interest margin (NIM) & $\begin{array}{l}\text { Interest income minus interest expenses/interest } \\
\text { earning assets }\end{array}$ & Bankscope \\
\hline $\begin{array}{l}\text { Pre-tax operating income } \\
\text { (POI) }\end{array}$ & Pre-tax operating assets/total assets & Bankscope \\
\hline \multicolumn{3}{|c|}{ B. Independent Variables of our main interest } \\
\hline Central bank’s assets (CBA) & $\begin{array}{l}\text { Claims on domestic real nonfinancial sector by the } \\
\text { Central Bank }\end{array}$ & $\begin{array}{l}\text { International Financial } \\
\text { Statistics (IFS), } \\
\text { International Monetary } \\
\text { Fund (IMF). }\end{array}$ \\
\hline Excess reserves (EXC_RES) & $\begin{array}{l}\text { The amount of money that a bank has on deposit } \\
\text { with the Federal Reserve that is above what is } \\
\text { required by the Federal Reserve. }\end{array}$ & Fed Bank of St. Louis \\
\hline $\begin{array}{l}\text { Federal Deposit insurance } \\
\text { coverage (FDIC) }\end{array}$ & $\begin{array}{l}\text { Bank specific dummy, that takes the value of } 0 \text { if } \\
\text { banks' deposit are not insured by the Fed while } 1 \text { if } \\
\text { banks' deposit are insured. }\end{array}$ & Fed Bank of St. Louis \\
\hline \multicolumn{3}{|l|}{ C. Other bank-specific } \\
\hline$\overline{\text { SIZE }}$ & Natural logarithm of real total assets & Bankscope \\
\hline E/TA & Equity/total assets & Bankscope \\
\hline $\mathrm{LA} / \mathrm{TA}$ & Loans/total assets & Bankscope \\
\hline LIQ/TA & $\begin{array}{l}\text { Liquid assets/total assets } \\
(1+\mathrm{ROE}) / \mathrm{sdROE} \text { where ROE is the return on equity }\end{array}$ & Bankscope \\
\hline Z-SCORE & $\begin{array}{l}\text { and sdROE is the standard deviation of return on } \\
\text { equity (Boyd and Graham, 1986) }\end{array}$ & Authors' estimation \\
\hline \multicolumn{3}{|c|}{ D. Country level and state-level explanatory variables } \\
\hline GDP gr & $\begin{array}{l}\text { Gross Domestic Product (GDP) changes from one } \\
\text { year to another }\end{array}$ & Fed Bank of St. Louis \\
\hline INFL & Inflation & Fed Bank of St. Louis \\
\hline UEMP & Unemployment & Fed Bank of St. Louis \\
\hline NPLs & Non-performing loans (state level)/total loans & Fed Bank of St. Louis \\
\hline Fed rate & Federal fund rate & Fed Bank of St. Louis \\
\hline
\end{tabular}


Table 2. Descriptive statistics of the variables used in the empirical analysis.

\begin{tabular}{|c|c|c|c|c|}
\hline Variable & Mean & Std. dv. & Min. & Max. \\
\hline \multicolumn{5}{|c|}{ A. Dependent Variables } \\
\hline ROA & 0.6 & 4.47 & -72.49 & 35.51 \\
\hline ROE & 0.03 & 0.34 & -9.93 & 8.00 \\
\hline NIM & 4.02 & 2.84 & -427.00 & 406.15 \\
\hline POI & 17.4 & 15.31 & -25.49 & 194.55 \\
\hline \multicolumn{5}{|c|}{ B. Independent Variables of our main interest } \\
\hline$\overline{\mathrm{CBA}}$ & 5.77 & 0.23 & -5.62 & 4.6 \\
\hline EXC_RES & 14.06 & 1.04 & 7.38 & 14.68 \\
\hline FDIC & 0.67 & 0.47 & 0 & 1 \\
\hline \multicolumn{5}{|c|}{ C. Bank-specific control variables } \\
\hline SIZE & 12.18 & 1.34 & 4.67 & 21.11 \\
\hline $\mathrm{E} / \mathrm{TA}$ & 7.94 & 2.79 & -11.75 & 12.99 \\
\hline LA/TA & 71.80 & 9.26 & 50.03 & 97.14 \\
\hline $\mathrm{LIQ} / \mathrm{TA}$ & 72.56 & 13.64 & 51.68 & 99.54 \\
\hline Z-SCORE & -1.27 & 1.84 & -7.94 & 4.49 \\
\hline \multicolumn{5}{|c|}{ D. Country level and state-level explanatory variables } \\
\hline GDP gr & 0.51 & 0.47 & -2.11 & 1.12 \\
\hline INFL & 1.75 & 0.45 & 0.73 & 2.50 \\
\hline UEMP & 8.34 & 0.89 & 4.50 & 9.50 \\
\hline NPLs & 2.74 & 1.37 & 0.12 & 9.32 \\
\hline Fed rate & 0.19 & 0.52 & 0.07 & 5.09 \\
\hline \multicolumn{5}{|c|}{$\begin{array}{l}\text { Notes: our final sample includes } 88888 \text { observations after removing all errors and inconsistencies. The Table } \\
\text { shows the basic descriptive statistics (mean, std.dv., min., max.) of all our dependent and independent variables. } \\
\text { Our dependent variables are: ROA; ROE; NIM; POI. Our independent variables of our main interest are: CBA; } \\
\text { EXC_RES; FDIC. Other bank-specific independent control variables: SIZE; E/TA; LA/TA; LIQ/TA; Z-SCORE; } \\
\text { Country-level and state-level independent variables: NPLs, Fed rate, GDP gr, INFL, UEMP. }\end{array}$} \\
\hline
\end{tabular}


Table 3. The effect of UMP on the US bank performance (fixed effect regressions).

\begin{tabular}{|c|c|c|c|c|c|c|c|c|}
\hline $\begin{array}{l}\text { Dependent } \\
\text { Variables }\end{array}$ & \multicolumn{2}{|c|}{ ROE } & \multicolumn{2}{|c|}{ ROA } & \multicolumn{2}{|c|}{ NIM } & \multicolumn{2}{|c|}{ POI } \\
\hline CBA & $\begin{array}{c}-0.890 * * * \\
(0.255)\end{array}$ & & $\begin{array}{c}-0.384^{* * *} \\
(0.117)\end{array}$ & & $\begin{array}{c}-0.154^{* *} \\
(0.069)\end{array}$ & & $\begin{array}{c}-0.721^{* *} \\
(0.318)\end{array}$ & \\
\hline EXC_RES & & $\begin{array}{c}-0.707 * * * \\
(0.046)\end{array}$ & & $\begin{array}{c}-0.240 * * * \\
(0.030)\end{array}$ & & $\begin{array}{c}-0.684 * * * \\
(0.211)\end{array}$ & & $\begin{array}{c}-0.291^{* * *} \\
(0.052)\end{array}$ \\
\hline SIZE & $\begin{array}{c}0.982 * * * \\
(0.301)\end{array}$ & $\begin{array}{c}0.996 * * * \\
(0.301)\end{array}$ & $\begin{array}{c}0.559 * * * \\
(0.170)\end{array}$ & $\begin{array}{c}0.572^{* * *} \\
(0.169)\end{array}$ & $\begin{array}{c}0.163 \\
(0.133)\end{array}$ & $\begin{array}{c}0.150 \\
(0.160)\end{array}$ & $\begin{array}{c}0.195 \\
(0.553)\end{array}$ & $\begin{array}{c}0.137 \\
(0.554)\end{array}$ \\
\hline LA/TA & $\begin{array}{c}0.402 * * * \\
(0.109)\end{array}$ & $\begin{array}{c}0.394 * * * \\
(0.042)\end{array}$ & $\begin{array}{c}0.029 * * * \\
(0.003)\end{array}$ & $\begin{array}{c}0.027 * * * \\
(0.009)\end{array}$ & $\begin{array}{c}0.020^{* * *} \\
(0.002)\end{array}$ & $\begin{array}{c}0.015^{* * *} \\
(0.002)\end{array}$ & $\begin{array}{c}0.331 * * * \\
(0.101)\end{array}$ & $\begin{array}{c}0.313^{* * * *} \\
(0.097)\end{array}$ \\
\hline $\mathrm{E} / \mathrm{TA}$ & $\begin{array}{c}0.192 * * * \\
(0.030)\end{array}$ & $\begin{array}{c}0.193 * * * \\
(0.026)\end{array}$ & $\begin{array}{c}0.064 * * * \\
(0.021)\end{array}$ & $\begin{array}{c}0.062 * * * \\
(0.021)\end{array}$ & $\begin{array}{c}0.026 * * \\
(0.013)\end{array}$ & $\begin{array}{c}0.041^{* *} \\
(0.017)\end{array}$ & $\begin{array}{c}0.067 \\
(0.043)\end{array}$ & $\begin{array}{c}0.068 \\
(0.043)\end{array}$ \\
\hline LIQ/TA & $\begin{array}{l}-0.007 \\
(0.005)\end{array}$ & $\begin{array}{l}-0.007 \\
(0.005)\end{array}$ & $\begin{array}{l}-0.001 \\
(0.002)\end{array}$ & $\begin{array}{c}-0.001 \\
(0.002)\end{array}$ & $\begin{array}{l}-0.001 \\
(0.001)\end{array}$ & $\begin{array}{l}-0.001 \\
(0.001)\end{array}$ & $\begin{array}{l}-0.001 \\
(0.001)\end{array}$ & $\begin{array}{l}-0.001 \\
(0.001)\end{array}$ \\
\hline Z-SCORE & $\begin{array}{c}0.755^{* * *} \\
(0.100)\end{array}$ & $\begin{array}{c}0.760 * * * \\
(0.139)\end{array}$ & $\begin{array}{c}0.819 * * * \\
(0.107)\end{array}$ & $\begin{array}{c}0.820^{* * *} \\
(0.177)\end{array}$ & $\begin{array}{c}0.093^{* * *} \\
(0.018)\end{array}$ & $\begin{array}{c}0.111^{* * *} \\
(0.014)\end{array}$ & $\begin{array}{c}0.331^{* * *} \\
(0.070)\end{array}$ & $\begin{array}{c}0.329 * * * \\
(0.069)\end{array}$ \\
\hline FDIC & $\begin{array}{c}-0.308 * \\
(0.180)\end{array}$ & $\begin{array}{c}-0.441 * * * \\
(0.123)\end{array}$ & $\begin{array}{c}-0.372 * \\
(0.215)\end{array}$ & $\begin{array}{c}-0.281 * * * \\
(0.061)\end{array}$ & $\begin{array}{c}-0.109 * * \\
(0.051)\end{array}$ & $\begin{array}{c}-0.149 * * * \\
(0.045)\end{array}$ & $\begin{array}{c}-0.952 * * * \\
(0.191)\end{array}$ & $\begin{array}{c}-0.313 * * * \\
(0.104)\end{array}$ \\
\hline CBA*FDIC & $\begin{array}{l}0.540^{*} \\
(0.311)\end{array}$ & & $\begin{array}{c}0.770 \\
(0.487)\end{array}$ & & $\begin{array}{c}0.185^{* *} \\
(0.088)\end{array}$ & & $\begin{array}{c}0.161 * * * \\
(0.033)\end{array}$ & \\
\hline EXC_RES*FDIC & & $\begin{array}{c}0.140 * * \\
(0.069)\end{array}$ & & $\begin{array}{l}0.685^{*} \\
(0.392)\end{array}$ & & $\begin{array}{c}0.655^{* *} \\
(0.265)\end{array}$ & & $\begin{array}{c}0.853^{* * *} \\
(0.196)\end{array}$ \\
\hline Fed rate & $\begin{array}{c}0.368 * * * \\
(0.100)\end{array}$ & $\begin{array}{c}0.126^{* * *} \\
(0.032)\end{array}$ & $\begin{array}{c}0.356 * * * \\
(0.038)\end{array}$ & $\begin{array}{c}0.146^{* * *} \\
(0.025)\end{array}$ & $\begin{array}{c}0.184 * * * \\
(0.020)\end{array}$ & $\begin{array}{c}0.096 * * * \\
(0.014)\end{array}$ & $\begin{array}{c}0.791^{* * *} \\
(0.059)\end{array}$ & $\begin{array}{c}0.549 * * * \\
(0.052)\end{array}$ \\
\hline NPLs & $\begin{array}{c}-0.299 * * * \\
(0.040)\end{array}$ & $\begin{array}{c}-0.193^{* * *} \\
(0.041)\end{array}$ & $\begin{array}{c}-0.217^{* * *} \\
(0.020)\end{array}$ & $\begin{array}{c}-0.193^{* * *} \\
(0.018)\end{array}$ & $\begin{array}{c}-0.056^{* * *} \\
(0.010)\end{array}$ & $\begin{array}{l}-0.012 \\
(0.013)\end{array}$ & $\begin{array}{l}-0.009 \\
(0.010)\end{array}$ & $\begin{array}{l}-0.029 \\
(0.040)\end{array}$ \\
\hline GDP gr & $\begin{array}{c}-0.176^{* * *} \\
(0.036)\end{array}$ & $\begin{array}{c}-0.257 * * * \\
(0.038)\end{array}$ & $\begin{array}{l}-0.013 \\
(0.018)\end{array}$ & $\begin{array}{c}-0.018 \\
(0.019)\end{array}$ & $\begin{array}{c}-0.059 * * * \\
(0.011)\end{array}$ & $\begin{array}{c}0.025 * * * \\
(0.009)\end{array}$ & $\begin{array}{c}-0.297 * * * \\
(0.027)\end{array}$ & $\begin{array}{c}-0.349 * * * \\
(0.029)\end{array}$ \\
\hline INFL & $\begin{array}{c}-0.162 * * * \\
(0.030)\end{array}$ & $\begin{array}{c}-0.176 * * * \\
(0.029)\end{array}$ & $\begin{array}{c}-0.043 * * \\
(0.017)\end{array}$ & $\begin{array}{c}-0.068 * * * \\
(0.018)\end{array}$ & $\begin{array}{c}-0.066 * * * \\
(0.010)\end{array}$ & $\begin{array}{c}-0.072 * * * \\
(0.012)\end{array}$ & $\begin{array}{c}-0.676 * * * \\
(0.042)\end{array}$ & $\begin{array}{c}-0.644 * * * \\
(0.143)\end{array}$ \\
\hline UEMP & $\begin{array}{c}-0.020 \\
(0.040)\end{array}$ & $\begin{array}{c}-0.092 * * \\
(0.041)\end{array}$ & $\begin{array}{c}-0.055^{* * *} \\
(0.018)\end{array}$ & $\begin{array}{c}-0.082 * * * \\
(0.018)\end{array}$ & $\begin{array}{c}-0.086^{* * *} \\
(0.018)\end{array}$ & $\begin{array}{c}-0.095 * * * \\
(0.030)\end{array}$ & $\begin{array}{c}-0.065 \\
(0.042)\end{array}$ & $\begin{array}{c}-0.026 \\
(0.043)\end{array}$ \\
\hline Constant & $\begin{array}{c}1.345^{* * *} \\
(0.358)\end{array}$ & $\begin{array}{c}2.124 * * * \\
(0.376)\end{array}$ & $\begin{array}{c}-1.015^{* * *} \\
(0.235)\end{array}$ & $\begin{array}{c}7.832 * * * \\
(2.362)\end{array}$ & $\begin{array}{c}4.364^{* * *} \\
(1.706)\end{array}$ & $\begin{array}{c}2.814 \\
(1.946)\end{array}$ & $\begin{array}{c}4.389 * * * \\
(0.637)\end{array}$ & $\begin{array}{c}4.293 * * * \\
(0.663)\end{array}$ \\
\hline F-test & $75.40^{* * *}$ & $76.89 * * *$ & $90.88 * * *$ & $94.07 * * *$ & $85.33^{* * *}$ & $63.49 * * *$ & $130.92 * * *$ & $134.37^{* * *}$ \\
\hline Observations & 88888 & 88888 & 88888 & 88888 & 88888 & 88888 & 88888 & 88888 \\
\hline R-squared & 0.140 & 0.1428 & 0.106 & 0.107 & 0.11 & 0.127 & 0.1684 & 0.169 \\
\hline Number of banks & 6771 & 6771 & 6771 & 6771 & 6771 & 6771 & 6771 & 6771 \\
\hline
\end{tabular}

Notes: the Table shows fixed effect regressions with ROA, ROE, NIM and POI as dependent variables. Our independent variables of our main interest: CBA; EXC_RES; FDIC, EXC_RES*FDIC (cross-term), CBA* FDIC (cross term). Other bank-specific independent control variables: SIZE; E/TA; LA/TA; LIQ/TA; Z-SCORE; Country level and state-level independent variables: NPLs, GDP gr, INFL, UEMP, Fed rate. We check that there is not a high level of correlation between the variables used in the models. ${ }^{* * *}, * *$ and $*$ indicate $1 \%, 5 \%$ and $10 \%$ significance levels respectively. Robust standard errors clustered by quarter and bank are in parentheses. 
Table 4. The effect of UMP on the US bank performance (dynamic panel regressions).

\begin{tabular}{|c|c|c|c|c|c|c|c|c|}
\hline \multirow{2}{*}{$\begin{array}{l}\begin{array}{l}\text { Dependent } \\
\text { Variables }\end{array} \\
\text { L.Perf. }\end{array}$} & \multicolumn{2}{|c|}{ ROA } & \multicolumn{2}{|c|}{ ROE } & \multicolumn{2}{|c|}{ NIM } & \multicolumn{2}{|c|}{ POI } \\
\hline & $\begin{array}{c}0.584^{* *} \\
(0.248)\end{array}$ & $\begin{array}{r}0.572^{* *} \\
(0.244)\end{array}$ & $\begin{array}{c}0.256 * * * \\
(0.029)\end{array}$ & $\begin{array}{c}0.244^{* * * *} \\
(0.028)\end{array}$ & $\begin{array}{c}0.957 * * * \\
(0.169)\end{array}$ & $\begin{array}{c}0.970^{* * *} \\
(0.244)\end{array}$ & $\begin{array}{c}0.926 * * * \\
(0.097)\end{array}$ & $\begin{array}{c}0.941 * * * \\
(0.197)\end{array}$ \\
\hline CBA & $\begin{array}{c}-0.581^{*} \\
(0.332)\end{array}$ & & $\begin{array}{l}-0.356^{* * *} \\
(0.071)\end{array}$ & & $\begin{array}{c}-0.824^{*} \\
(0.487)\end{array}$ & & $\begin{array}{c}-0.222 * * \\
(0.101)\end{array}$ & \\
\hline EXC_RES & & $\begin{array}{c}-0.102 * \\
(0.052)\end{array}$ & & $\begin{array}{c}-0.709 * * * \\
(0.118)\end{array}$ & & $\begin{array}{c}-0.062 * * * \\
(0.004)\end{array}$ & & $\begin{array}{l}-0.187 * \\
(0.097)\end{array}$ \\
\hline SIZE & $\begin{array}{l}0.173^{*} \\
(0.101)\end{array}$ & $\begin{array}{l}0.184^{*} \\
(0.107)\end{array}$ & $\begin{array}{c}0.204 \\
(0.295)\end{array}$ & $\begin{array}{l}0.192 \\
\quad(0.301)\end{array}$ & $\begin{array}{c}0.083 \\
(0.081)\end{array}$ & $\begin{array}{c}0.123 * * * \\
(0.032)\end{array}$ & $\begin{array}{c}0.300 \\
(0.225)\end{array}$ & $\begin{array}{c}0.322 \\
(0.280)\end{array}$ \\
\hline $\mathrm{LA} / \mathrm{TA}$ & $\begin{array}{c}0.107 \\
(0.081)\end{array}$ & $\begin{array}{c}0.110 \\
(0.088)\end{array}$ & $\begin{array}{c}0.412^{* * *} \\
(0.108)\end{array}$ & $\begin{array}{c}0.367 * * * \\
(0.110)\end{array}$ & $\begin{array}{c}0.008 * * \\
(0.003)\end{array}$ & $\begin{array}{c}0.007 \\
(0.005)\end{array}$ & $\begin{array}{c}0.302 \\
(0.454)\end{array}$ & $\begin{array}{c}0.274 \\
(0.255)\end{array}$ \\
\hline $\mathrm{E} / \mathrm{TA}$ & $\begin{array}{l}0.496^{*} \\
(0.279)\end{array}$ & $\begin{array}{l}0.494 * \\
(0.282)\end{array}$ & $\begin{array}{c}0.186 * * * \\
(0.027)\end{array}$ & $\begin{array}{c}0.179 * * * \\
(0.028)\end{array}$ & $\begin{array}{c}0.012 \\
(0.010)\end{array}$ & $\begin{array}{c}0.012^{* * *} \\
(0.004)\end{array}$ & $\begin{array}{c}0.180 \\
(0.148)\end{array}$ & $\begin{array}{c}0.163 \\
(0.139)\end{array}$ \\
\hline LIQ/TA & $\begin{array}{l}-0.001 \\
(0.001)\end{array}$ & $\begin{array}{c}-0.001 \\
(0.001)\end{array}$ & $\begin{array}{c}-0.001 \\
(0.001)\end{array}$ & $\begin{array}{c}-0.001 \\
(0.001)\end{array}$ & $\begin{array}{l}-0.001 \\
(0.001)\end{array}$ & $\begin{array}{l}-0.001 \\
(0.001)\end{array}$ & $\begin{array}{c}-0.001 \\
(0.001)\end{array}$ & $\begin{array}{c}-0.001 \\
(0.001)\end{array}$ \\
\hline Z-SCORE & $\begin{array}{c}0.232 \\
(0.215)\end{array}$ & $\begin{array}{c}0.171 \\
(0.136)\end{array}$ & $\begin{array}{c}0.787 * * * \\
(0.071)\end{array}$ & $\begin{array}{r}0.765^{* * *} \\
(0.074)\end{array}$ & $\begin{array}{l}0.056^{*} \\
(0.028)\end{array}$ & $\begin{array}{c}0.049 * * * \\
(0.010)\end{array}$ & $\begin{array}{c}0.016 \\
(0.015)\end{array}$ & $\begin{array}{c}0.045^{* *} \\
(0.016)\end{array}$ \\
\hline FDIC & $\begin{array}{l}-0.546^{*} \\
(0.328)\end{array}$ & $\begin{array}{l}-0.210^{*} \\
(0.121)\end{array}$ & $\begin{array}{c}-0.318 * * * \\
(0.063)\end{array}$ & $\begin{array}{c}-0.141 * * * \\
(0.036)\end{array}$ & $\begin{array}{l}-0.319 \\
(0.484)\end{array}$ & $\begin{array}{c}-0.212 * * * \\
(0.035)\end{array}$ & $\begin{array}{c}-0.221 * * \\
(0.110)\end{array}$ & $\begin{array}{l}-0.179 \\
(0.164)\end{array}$ \\
\hline CBA*FDIC & $\begin{array}{l}0.124^{*} \\
(0.072)\end{array}$ & & $\begin{array}{l}0.648^{* * *} \\
(0.122)\end{array}$ & & $\begin{array}{c}0.606 \\
(0.709)\end{array}$ & & $\begin{array}{c}0.482^{* *} \\
(0.239)\end{array}$ & \\
\hline EXC_RES*FDIC & & $\begin{array}{l}0.263^{*} \\
(0.141)\end{array}$ & & $\begin{array}{r}0.137 * * * \\
(0.028)\end{array}$ & & $\begin{array}{c}0.047 * * * \\
(0.012)\end{array}$ & & $\begin{array}{c}0.366 \\
(0.260)\end{array}$ \\
\hline Fed rate & $\begin{array}{c}0.536 * * * \\
(0.091)\end{array}$ & $\begin{array}{c}0.579 * * * \\
(0.094)\end{array}$ & $\begin{array}{c}0.347 * * * \\
(0.071)\end{array}$ & $\begin{array}{c}0.280 * * * \\
(0.066)\end{array}$ & $\begin{array}{c}0.121 * * * \\
(0.035)\end{array}$ & $\begin{array}{l}0.102 * * * \\
(0.011)\end{array}$ & $\begin{array}{c}0.125^{* * *} \\
(0.033)\end{array}$ & $\begin{array}{c}0.996 * * * \\
(0.314)\end{array}$ \\
\hline NPLs & $\begin{array}{c}-0.124 * \\
(0.072)\end{array}$ & $\begin{array}{c}-0.109 * \\
(0.062)\end{array}$ & $\begin{array}{c}-0.275^{* * *} \\
(0.086)\end{array}$ & $\begin{array}{c}-0.247 * * * \\
(0.081)\end{array}$ & $\begin{array}{c}-0.061 \\
(0.068)\end{array}$ & $\begin{array}{l}-0.056^{* * *} \\
(0.010)\end{array}$ & $\begin{array}{c}-0.621 \\
(0.407)\end{array}$ & $\begin{array}{c}-0.535 \\
(0.351)\end{array}$ \\
\hline GDP gr & $\begin{array}{c}-0.334 * * * \\
(0.040)\end{array}$ & $\begin{array}{l}-0.013 \\
(0.034)\end{array}$ & $\begin{array}{c}-0.091 * * * \\
(0.025)\end{array}$ & $\begin{array}{c}-0.797 * * * \\
(0.245)\end{array}$ & $\begin{array}{c}-0.079 * * * \\
(0.011)\end{array}$ & $\begin{array}{l}-0.072 * * \\
(0.034)\end{array}$ & $\begin{array}{l}-0.235 \\
(0.212)\end{array}$ & $\begin{array}{l}-0.039 \\
(0.029)\end{array}$ \\
\hline INFL & $\begin{array}{l}-0.106 \\
(0.095)\end{array}$ & $\begin{array}{l}-0.011 \\
(0.068)\end{array}$ & $\begin{array}{l}-0.006 \\
(0.005)\end{array}$ & $\begin{array}{l}-0.262 \\
(0.233)\end{array}$ & $\begin{array}{c}-0.018^{*} \\
(0.010)\end{array}$ & $\begin{array}{l}-0.033^{*} \\
(0.017)\end{array}$ & $\begin{array}{c}0.586 \\
(0.395)\end{array}$ & $\begin{array}{c}-0.541 * * * \\
(0.125)\end{array}$ \\
\hline UEMP & $\begin{array}{l}-0.040 \\
(0.054)\end{array}$ & $\begin{array}{l}-0.055 \\
(0.062)\end{array}$ & $\begin{array}{l}-0.116 \\
(0.139)\end{array}$ & $\begin{array}{c}-0.205^{* *} \\
(0.390)\end{array}$ & $\begin{array}{l}-0.008 \\
(0.023)\end{array}$ & $\begin{array}{r}-0.003 \\
(0.002)\end{array}$ & $\begin{array}{l}-0.121 \\
(0.113)\end{array}$ & $\begin{array}{c}-0.133 \\
(0.123)\end{array}$ \\
\hline Constant & $\begin{array}{c}1.397 * * * \\
(0.105)\end{array}$ & $\begin{array}{c}3.333 * * * \\
(0.741)\end{array}$ & $\begin{array}{c}1.718^{* * *} \\
(0.437)\end{array}$ & $\begin{array}{c}2.341 * * \\
(0.394)\end{array}$ & $\begin{array}{c}6.361 * * * \\
(0.669)\end{array}$ & $\begin{array}{l}3.249 * * * \\
(0.761)\end{array}$ & $\begin{array}{c}2.137 * * * \\
(0.536)\end{array}$ & $\begin{array}{c}3.403^{* * *} \\
(0.362)\end{array}$ \\
\hline Wald test & $240.09 * * *$ & $296.52 * * *$ & $760.87 * * *$ & $734.46 * * *$ & $5892.85^{* * *}$ & $113.09 * * *$ & $493.64 * * *$ & $511.05 * * *$ \\
\hline Hansen(p-value) & 0.377 & 0.179 & 0.522 & 0.183 & 0.179 & 0.146 & 0.526 & 0.273 \\
\hline $\mathrm{AR}(2)$ & 0.114 & 0.218 & 0.316 & 0.465 & 0.612 & 0.327 & 0.197 & 0.184 \\
\hline Number of banks & 6771 & 6771 & 6771 & 6771 & 6771 & 6771 & 6771 & 6771 \\
\hline
\end{tabular}

Notes: the Table shows dynamic panel regressions with ROA, ROE, NIM and POI as dependent variables. Our independent variables of our main interest: CBA; EXC_RES; FDIC, EXC_RES*FDIC (cross-term), CBA* FDIC (cross term). Other bank-specific independent control variables: SIZE; E/TA; LA/TA; LIQ/TA; Z-SCORE; Country level and state-level independent variables: NPLs, GDP gr, INFL, UEMP, Fed rate. We check that there is not a high level of correlation between the variables used in the models. ***, ** and * indicate $1 \%, 5 \%$ and $10 \%$ significance levels respectively. Robust standard errors clustered by quarter and bank are in parentheses. 
Table 5. Dynamic panel results of the effect of CBA and EXC_RES on bank performance based on asset diversification classification.

\begin{tabular}{|c|c|c|c|c|c|c|}
\hline Dependent Var. ROA & \multicolumn{2}{|c|}{$\begin{array}{c}\text { Low level of asset } \\
\text { diversification }\end{array}$} & \multicolumn{2}{|c|}{$\begin{array}{c}\text { Medium level of asset } \\
\text { diversification }\end{array}$} & \multicolumn{2}{|c|}{$\begin{array}{l}\text { High level of asset } \\
\text { diversification }\end{array}$} \\
\hline L.ROA & $\begin{array}{c}0.428^{* * *} \\
(0.143)\end{array}$ & $\begin{array}{l}0.365 * * \\
(0.164)\end{array}$ & $\begin{array}{l}0.069 * * \\
(0.021)\end{array}$ & $\begin{array}{l}0.094^{*} \\
(0.051)\end{array}$ & $\begin{array}{c}0.179 * * * \\
(0.049)\end{array}$ & $\begin{array}{c}0.196^{* * *} \\
(0.043)\end{array}$ \\
\hline CBA*ASSETDIV & $\begin{array}{c}-0.316^{* *} \\
(0.141)\end{array}$ & & $\begin{array}{c}-0.301^{* *} \\
(0.135)\end{array}$ & & $\begin{array}{r}-0.289 * \\
(0.159)\end{array}$ & \\
\hline EXC_RES*ASSETDIV & & $\begin{array}{c}-0.429 * * * \\
(0.155)\end{array}$ & & $\begin{array}{c}-0.665^{* *} \\
(0.276)\end{array}$ & & $\begin{array}{l}-0.171 \\
(0.136)\end{array}$ \\
\hline SIZE & $\begin{array}{c}0.189 \\
(0.172)\end{array}$ & $\begin{array}{c}0.163^{* *} \\
(0.071)\end{array}$ & $\begin{array}{c}0.028 \\
(0.019)\end{array}$ & $\begin{array}{c}0.252 \\
(0.232)\end{array}$ & $\begin{array}{c}0.069 \\
(0.045)\end{array}$ & $\begin{array}{l}0.374^{*} \\
(0.220)\end{array}$ \\
\hline $\mathrm{LA} / \mathrm{TA}$ & $\begin{array}{c}0.844 \\
(0.751)\end{array}$ & $\begin{array}{c}0.367 \\
(0.225)\end{array}$ & $\begin{array}{c}0.035 \\
(0.047)\end{array}$ & $\begin{array}{c}0.028 \\
(0.025)\end{array}$ & $\begin{array}{c}0.136 * * * \\
(0.035)\end{array}$ & $\begin{array}{c}0.019 \\
(0.024)\end{array}$ \\
\hline $\mathrm{E} / \mathrm{TA}$ & $\begin{array}{c}0.284 * * \\
(0.137)\end{array}$ & $\begin{array}{c}0.224^{* * *} \\
(0.071)\end{array}$ & $\begin{array}{c}0.139 \\
(0.091)\end{array}$ & $\begin{array}{c}0.137 \\
(0.088)\end{array}$ & $\begin{array}{c}0.184 * * * \\
(0.045)\end{array}$ & $\begin{array}{c}0.163 * * * \\
(0.062)\end{array}$ \\
\hline $\mathrm{LIQ} / \mathrm{TA}$ & $\begin{array}{l}-0.004 * * \\
(0.002)\end{array}$ & $\begin{array}{l}-0.001 \\
(0.000)\end{array}$ & $\begin{array}{c}-0.014^{* *} \\
(0.006)\end{array}$ & $\begin{array}{l}-0.010 \\
(0.006)\end{array}$ & $\begin{array}{l}-0.001 \\
(0.000)\end{array}$ & $\begin{array}{l}-0.001 \\
(0.001)\end{array}$ \\
\hline Z-SCORE & $\begin{array}{l}0.284 * * \\
(0.134)\end{array}$ & $\begin{array}{c}0.141^{* * *} \\
(0.049)\end{array}$ & $\begin{array}{c}0.387 * * * \\
(0.108)\end{array}$ & $\begin{array}{c}0.493 * * * \\
(0.074)\end{array}$ & $\begin{array}{l}0.300^{* *} \\
(0.139)\end{array}$ & $\begin{array}{c}0.615^{* * *} \\
(0.114)\end{array}$ \\
\hline ASSETDIV & $\begin{array}{c}0.257 * * \\
(0.126)\end{array}$ & $\begin{array}{c}0.975^{* * *} \\
(0.356)\end{array}$ & $\begin{array}{l}0.114 * * \\
(0.044)\end{array}$ & $\begin{array}{l}0.876 * * \\
(0.389)\end{array}$ & $\begin{array}{l}0.101^{*} \\
(0.057)\end{array}$ & $\begin{array}{l}0.304^{*} \\
(0.182)\end{array}$ \\
\hline $\begin{array}{l}\text { Time effects } \\
\text { Bank effects }\end{array}$ & $\begin{array}{l}\text { Yes } \\
\text { Yes }\end{array}$ & $\begin{array}{l}\text { Yes } \\
\text { Yes }\end{array}$ & $\begin{array}{l}\text { Yes } \\
\text { Yes }\end{array}$ & $\begin{array}{l}\text { Yes } \\
\text { Yes }\end{array}$ & $\begin{array}{l}\text { Yes } \\
\text { Yes }\end{array}$ & $\begin{array}{l}\text { Yes } \\
\text { Yes }\end{array}$ \\
\hline Constant & $\begin{array}{l}3.363^{*} \\
(0.176)\end{array}$ & $\begin{array}{c}2.834^{* * *} \\
(0.103)\end{array}$ & $\begin{array}{c}3.544^{* * *} \\
(2.974)\end{array}$ & $\begin{array}{c}5.444^{* * *} \\
(2.118)\end{array}$ & $\begin{array}{c}2.993 * * * \\
(0.256)\end{array}$ & $\begin{array}{c}3.139 * * * \\
(0.511)\end{array}$ \\
\hline Wald chi2 & $176.37 * * *$ & $111.02 * * *$ & $154.13^{* * *}$ & $1349.46 * * *$ & $806.59 * * *$ & $760.11^{* * *}$ \\
\hline Observations & 22448 & 22448 & 36660 & 36660 & 29780 & 29780 \\
\hline Hansen(p-value) & 0.515 & 0.132 & 0.185 & 0.125 & 0.212 & 0.462 \\
\hline $\operatorname{AR}(2)$ & 0.697 & 0.180 & 0.595 & 0.904 & 0.381 & 0.328 \\
\hline Number of banks & 2194 & 2194 & 3558 & 3558 & 1019 & 1019 \\
\hline
\end{tabular}

Notes: the Table shows dynamic panel regressions with ROA as dependent variable across three different level of bank asset diversification (low, medium and high percentile $(>25 \%, 25 \%<>75 \%, 75 \%<$ )). Our independent variables of our main interest: CBA*ASSETDIV and EXC_RES*ASSETDIVE (interaction terms). Other bankspecific independent control variables: SIZE; E/TA; LA/TA; LIQ/TA; Z-SCORE; ASSETDIV. Hansen test stands for the p-value of the J-statistic for over-identifying restrictions. We check that there is not a high level of correlation between the variables used in the models. $* * *, * *$ and * indicate $1 \%, 5 \%$ and $10 \%$ significance levels respectively. Robust standard errors clustered by quarter and bank are in parentheses. 
Table 6. Dynamic panel results of the effect of CBA and EXC_RES on bank performance based on deposits over total assets ratio classification.

\begin{tabular}{|c|c|c|c|c|c|c|}
\hline \multirow{2}{*}{$\begin{array}{l}\text { Dependent Var. ROA } \\
\text { L.ROA }\end{array}$} & \multicolumn{2}{|c|}{$\begin{array}{c}\text { Low level of } \\
\text { deposits/total assets }\end{array}$} & \multicolumn{2}{|c|}{$\begin{array}{c}\text { Medium level of } \\
\text { deposits/total assets }\end{array}$} & \multicolumn{2}{|c|}{$\begin{array}{c}\text { High level of deposits/total } \\
\text { assets }\end{array}$} \\
\hline & $\begin{array}{l}0.493^{* *} \\
(0.227)\end{array}$ & $\begin{array}{l}0.509 * * \\
(0.219)\end{array}$ & $\begin{array}{c}0.101^{* * *} \\
(0.016)\end{array}$ & $\begin{array}{l}0.065^{*} \\
(0.033)\end{array}$ & $\begin{array}{c}0.068^{* * *} \\
(0.018)\end{array}$ & $\begin{array}{l}0.046^{* *} \\
(0.019)\end{array}$ \\
\hline CBA*DEP/TA & $\begin{array}{l}-0.836^{*} \\
(0.503)\end{array}$ & & $\begin{array}{c}-0.673^{* *} \\
(0.301)\end{array}$ & & $\begin{array}{c}-0.920 * * * \\
(0.159)\end{array}$ & \\
\hline EXC_RES*DEP/TA & & $\begin{array}{l}-0.210^{*} \\
(0.116)\end{array}$ & & $\begin{array}{l}-0.325 * * \\
(0.071)\end{array}$ & & $\begin{array}{c}-0.137 * * * \\
(0.031)\end{array}$ \\
\hline SIZE & $\begin{array}{c}0.131 \\
(0.106)\end{array}$ & $\begin{array}{c}0.107 \\
(0.106)\end{array}$ & $\begin{array}{c}0.187 * * \\
(0.077)\end{array}$ & $\begin{array}{c}0.013 \\
(0.085)\end{array}$ & $\begin{array}{c}0.049 \\
(0.099)\end{array}$ & $\begin{array}{c}0.081 \\
(0.109)\end{array}$ \\
\hline $\mathrm{LA} / \mathrm{TA}$ & $\begin{array}{l}0.224^{*} \\
(0.123)\end{array}$ & $\begin{array}{l}0.231^{*} \\
(0.125)\end{array}$ & $\begin{array}{c}0.022^{* * *} \\
(0.004)\end{array}$ & $\begin{array}{c}0.001 \\
(0.000)\end{array}$ & $\begin{array}{c}0.003 \\
(0.006)\end{array}$ & $\begin{array}{c}0.002 \\
(0.006)\end{array}$ \\
\hline $\mathrm{E} / \mathrm{TA}$ & $\begin{array}{c}0.153 \\
(0.098)\end{array}$ & $\begin{array}{c}0.130 \\
(0.098)\end{array}$ & $\begin{array}{c}0.293^{* * *} \\
(0.093)\end{array}$ & $\begin{array}{c}0.159 * * * \\
(0.050)\end{array}$ & $\begin{array}{l}0.158 * * * \\
(0.548)\end{array}$ & $\begin{array}{c}0.134 * * * \\
(0.032)\end{array}$ \\
\hline LIQ/TA & $\begin{array}{l}-0.002 \\
(0.002)\end{array}$ & $\begin{array}{l}-0.002 \\
(0.002)\end{array}$ & $\begin{array}{c}-0.001 * * * \\
(0.000)\end{array}$ & $\begin{array}{c}-0.000 * * * \\
(0.000)\end{array}$ & $\begin{array}{c}-0.004 * * * \\
(0.001)\end{array}$ & $\begin{array}{c}-0.004 * * * \\
(0.001)\end{array}$ \\
\hline Z-SCORE & $\begin{array}{c}0.188 * * * \\
(0.053)\end{array}$ & $\begin{array}{c}0.199 * * * \\
(0.056)\end{array}$ & $\begin{array}{c}0.289 * * * \\
(0.023)\end{array}$ & $\begin{array}{c}0.464 * * * \\
(0.027)\end{array}$ & $\begin{array}{c}0.548 * * * \\
(0.044)\end{array}$ & $\begin{array}{l}0.576^{* * *} \\
(0.041)\end{array}$ \\
\hline $\mathrm{DEP} / \mathrm{TA}$ & $\begin{array}{l}0.402 * * \\
(0.192)\end{array}$ & $\begin{array}{l}0.288^{*} \\
(0.153)\end{array}$ & $\begin{array}{c}0.358 * * \\
(0.175)\end{array}$ & $\begin{array}{l}0.181^{* *} \\
(0.100)\end{array}$ & $\begin{array}{c}0.387 * * * \\
(0.094)\end{array}$ & $\begin{array}{l}0.839 * \\
(0.477)\end{array}$ \\
\hline Time effects & $\begin{array}{l}\text { Yes } \\
\text { Yes }\end{array}$ & $\begin{array}{l}\text { Yes } \\
\text { Yes }\end{array}$ & Yes & Yes & Yes & Yes \\
\hline $\begin{array}{l}\text { Bank effects } \\
\text { Constant }\end{array}$ & $\begin{array}{c}\text { Yes } \\
4.243^{* * *} \\
(0.176)\end{array}$ & $\begin{array}{c}\text { Yes } \\
2.598^{* * *} \\
(0.243)\end{array}$ & $\begin{array}{c}\text { Yes } \\
2.645^{* * *} \\
(0.826)\end{array}$ & $\begin{array}{l}\text { Yes } \\
6.001^{* * *} \\
(1.718)\end{array}$ & $\begin{array}{l}\text { Yes } \\
2.390^{* * *} \\
(0.146)\end{array}$ & $\begin{array}{l}\text { Yes } \\
3.412^{* * *} \\
(0.511)\end{array}$ \\
\hline Wald chi2 & $115.29 * * *$ & $124.85 * * *$ & $114.56 * * *$ & $331.94 * * *$ & $1709.26 * * *$ & $1699.11^{* * *}$ \\
\hline Observations & 22963 & 22963 & 46465 & 46465 & 19460 & 19460 \\
\hline Hansen(p-value) & 0.141 & 0.256 & 0.472 & 0.530 & 0.467 & 0.608 \\
\hline $\operatorname{AR}(2)$ & 0.118 & 0.116 & 0.219 & 0.174 & 0.137 & 0.231 \\
\hline Number of banks & 1586 & 1586 & 3398 & 3398 & 1787 & 1787 \\
\hline
\end{tabular}

Notes: the Table shows dynamic panel regressions with ROA as dependent variable across three different level of bank deposits over total assets ratio (low, medium and high percentile $(>25 \%, 25 \%<>75 \%, 75 \%<$ )). Our independent variables of our main interest: CBA*ASSETDIV and EXC_RES* DEP/TA (interaction terms). Other bank-specific independent control variables: SIZE; E/TA; LA/TA; LIQ/TA; Z-SCORE; DEP/TA. Hansen test is the p-value of the J-statistic for over-identifying restrictions. We check that there is not a high level of correlation between the variables used in the models. ${ }^{* * *}, * *$ and $*$ indicate $1 \%, 5 \%$ and $10 \%$ significance levels respectively. Robust standard errors clustered by quarter and bank are in parentheses. 
Table 7. Results of dynamic panel threshold estimation with Central bank's assets as threshold variable.

\begin{tabular}{lcr}
\hline \hline Threshold estimate & & \\
\hline CBA & & (5.560105-5.560105) \\
$95 \%$ confidence interval & S.E & \\
\hline \hline Impact of CBA & $-2.548^{* * *}$ & 0.662 \\
\hline$\lambda_{1}$ & $-4.075^{* * *}$ & 1.019 \\
$\lambda_{2}$ & & S.E \\
\hline \hline Impact of covariates & $0.400^{* * *}$ & 0.110 \\
\hline E/TA & $0.286^{* *}$ & 0.113 \\
SIZE & $-0.001^{* * *}$ & 0.000 \\
LIQ/TA & $0.041^{* * *}$ & 0.010 \\
LA/TA & $0.051^{* * *}$ & 0.010 \\
Z-SCORE & $-1.812^{* *}$ & 0.864 \\
FDIC & $0.302^{* *}$ & 0.148 \\
CBA*FDIC & 0.144 & 0.103 \\
Fed rate & $-0.138^{* * *}$ & 0.032 \\
NPLs & $-0.072^{* *}$ & 0.047 \\
GDP gr & -0.010 & 0.048 \\
INFL & $-0.123^{* *}$ & 0.055 \\
UEMP & $0.355^{* *}$ & 0.181 \\
$\delta$ & 82117 & \\
\hline Observations & 6384 & \\
Low regime & 75733 & \\
High regime & & \\
\hline
\end{tabular}

Notes: the Table reports the estimations for the dynamic panel threshold model. Each regime has at least $5 \%$ of the observations (Hansen, 1999). We denote as dependent variable banks' performance (perform f $_{i, t}$ ), while as the threshold and the regime dependent variable we impose the Central bank's assets $\left(C B A_{t}\right)$ which represents unconventional monetary easing. Following Bick (2007), the model accounts for regime dependent intercepts $(\delta)$. Our dependent variable is ROA. Our independent variables of our main interest: CBA; FDIC; CBA*FDIC (cross-term). Other bank-specific independent control variables: SIZE; E/TA; LA/TA; LIQ/TA; Z-SCORE; Country level and state-level independent variables: NPLs, GDP gr, INFL, UEMP, Fed rate. We check that there is not a high level of correlation between the variables used in the models. ***, ** and * indicate $1 \%, 5 \%$ and $10 \%$ significance levels respectively. Robust standard errors clustered by quarter and bank are in parentheses. 
Table 8.Results of dynamic panel threshold estimation with Excess Reserves as threshold variable.

\begin{tabular}{lcr}
\hline \hline Threshold estimate & & \\
\hline EXC_RES & & 13.9947 \\
95\% confidence interval & & \\
\hline \hline Impact of EXC_RES & & 0.112 \\
\hline$\lambda_{1}$ & $-0.428^{* * *}$ & 0.872 \\
$\lambda_{2}$ & $-3.368^{* * *}$ & S.E \\
\hline \hline Impact of covariates & & 0.100 \\
\hline E/TA & $0.400^{* * *}$ & 0.116 \\
SIZE & $0.303^{* *}$ & 0.000 \\
LIQ/TA & $-0.001^{* * *}$ & 0.010 \\
LA/TA & $0.039^{* * *}$ & 0.010 \\
Z-SCORE & $0.051^{* * *}$ & 0.620 \\
FDIC & $-1.806^{* *}$ & 0.043 \\
EXC_RES*FDIC & $0.123^{* *}$ & 0.096 \\
Fed rate & 0.148 & 0.030 \\
NPLs & $-0.150^{* * *}$ & 0.047 \\
GDP gr & $-0.137^{* *}$ & 0.075 \\
INFL & $-0.181^{* *}$ & 0.059 \\
UEMP & $-0.162^{* *}$ & 0.181 \\
$\delta$ & $0.402^{* *}$ & \\
\hline Observations & 82117 & \\
Low regime & 19426 & 62691 \\
High regime & & \\
\hline Not & & \\
\hline
\end{tabular}

Notes: the Table reports the estimations for the dynamic panel threshold model. Each regime has at least $5 \%$ of the observations (Hansen, 1999). We denote as dependent variable banks' performance $\left(\right.$ perform $\left._{i, t}\right)$, while as the threshold and the regime dependent variable we impose excess reserves $\left(C B A_{t}\right)$ which represents unconventional monetary easing. Following Bick (2007), the model accounts for regime dependent intercepts $(\delta)$. Our dependent variable is ROA. Our independent variables of our main interest: EXC_RES; FDIC; EXC_RES*FDIC (cross-term). Other bank-specific independent control variables: SIZE; E/TA; LA/TA; LIQ/TA; Z-SCORE; Country level and state-level independent variables: NPLs, GDP gr, INFL, UEMP, Fed rate. We check that there is not a high level of correlation between the variables used in the models. ${ }^{* * *}$, ** and $*$ indicate $1 \%, 5 \%$ and $10 \%$ significance levels respectively. Robust standard errors clustered by quarter and bank are in parentheses. 


\section{List of Figures}

Figure 1. Threshold value of central bank's assets and the classification of the low and high regime.

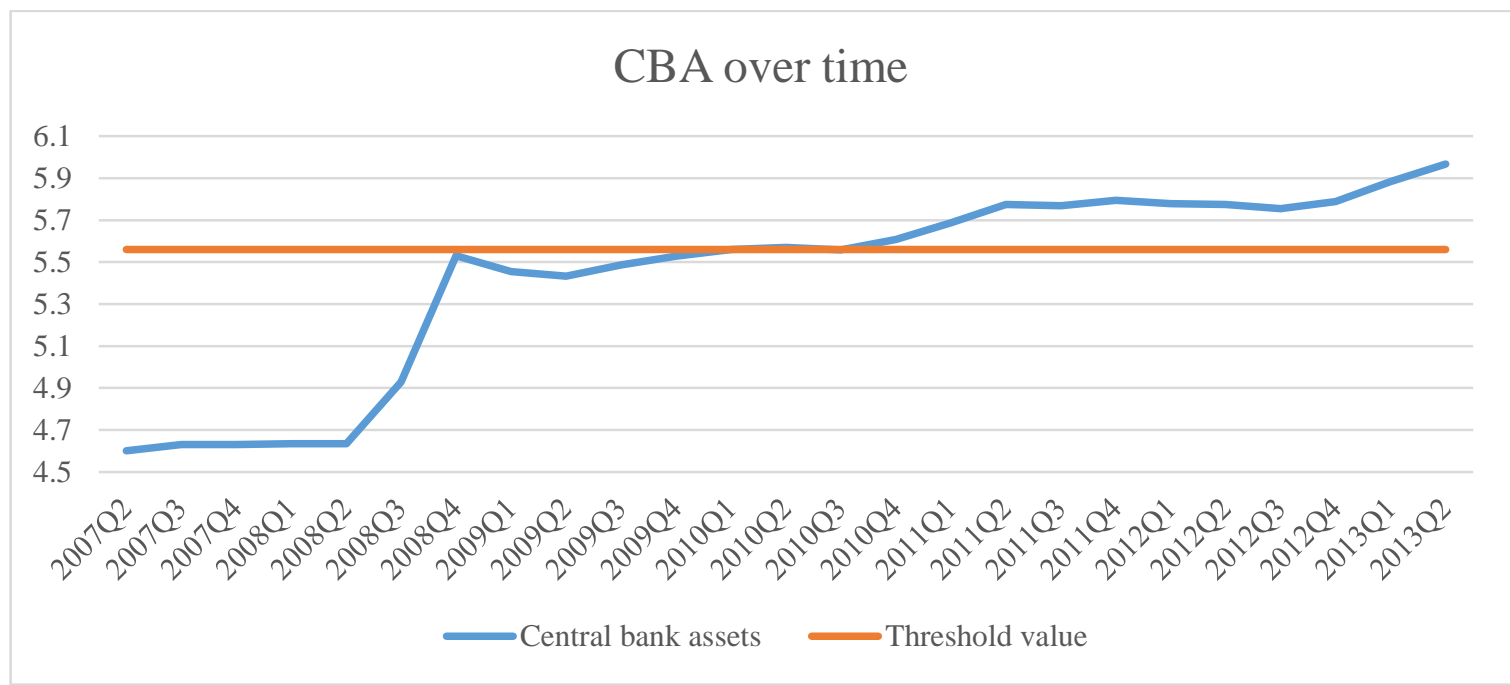

Notes: the Figure shows the threshold value of central bank's assets on bank performance which splits the sample into the high and low regime (2007Q2-2013Q2).

Figure 2. Threshold value of excess reserves and the classification of the low and high regime.

\section{EXC_RES over time}

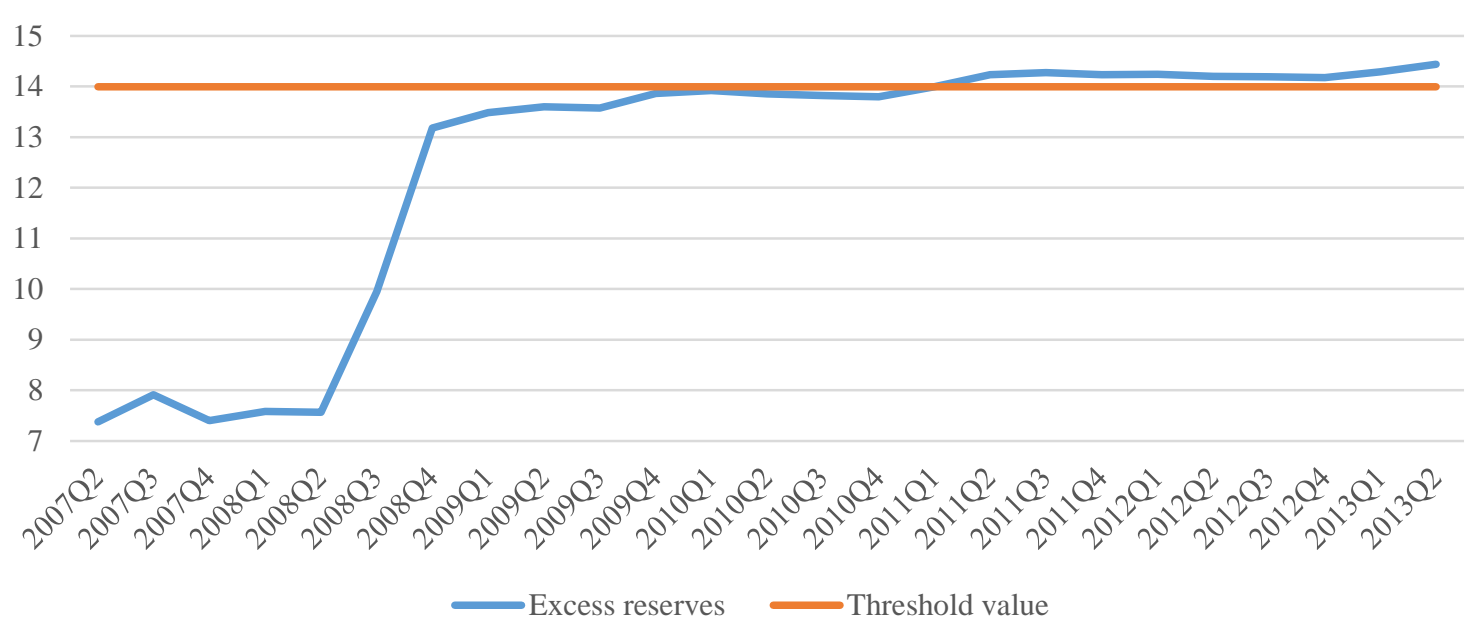

Notes: the Figure shows the threshold value of excess reserves on bank performance which splits the sample into the high and low regime (2007Q2-2013Q2). 